\title{
Review on the succession process of Pinus densiflora forests in South Korea: progressive and disturbance-driven succession
}

Yeonsook Choung ${ }^{*}$ (D) Jongsung Lee, Soyeon Cho and Jaesang Noh

\begin{abstract}
Background: Most of the Pinus densiflora forests, occupying the largest area, have been restored in South Korea since the 1970s. As young pioneer forests, the succession process is under way. Since the forests are distributed nationwide and are vulnerable to disturbances, the process may differ depending on the geography and/or site conditions. Therefore, we reviewed the direction, the seral communities, and the late-successional species of progressive and disturbance-driven succession nationwide in the cool-temperate zone through meta-analysis and empirical observations.
\end{abstract}

Main text: As a result of a meta-analysis of the direct succession and vertical structure, we found that the $P$. densiflora forest is in a directionally progressive succession, changing to the broadleaved forest after forming a mixed forest with its overwhelming successor, Quercus species (particularly Q. mongolica and Q. serrata). In dry stands in a relative sense, the Quercus species was favored occupying over $80 \%$ of the abundance of the succeeding species. Therefore, in dry stands, it is presumed that Quercus-dominated stage would last for a long time due to the current dominance and long life span, and eventually, it settles as Quercus-broadleaved forest with a site change. Contrary to this, it is presumed that in mesic stands where Quercus species do not occur or have low abundance, the late-successional broadleaved species settle early to form a co-dominant forest with multiple species. Due to geographical limits, the species composition of the two late-successional forests is different. Disturbances such as insect pests and fire retrogressed vulnerable $P$. densiflora forest for a while. However, it was mostly restored to the Quercus forest and is expected to be incorporated in the pathway of the dry stand.

Conclusions: We revealed the succession process of $P$. densiflora forests according to geography and moisture and found that stand moisture had a decisive effect on the species and abundance of the successor. Although the $P$. densiflora forest is undergoing structural changes, the forest is still young; so within a few decades, physiognomy is not likely to change. Therefore, the decrease in the forest area may be due to other causes such as disturbances and forest conversion rather than due to succession.

Keywords: Human-influenced, Japanese red pine, Korean red pine, Moisture, Oak, Quercus mongolica, Quercus serrata

* Correspondence: yschoung@kangwon.ac.kr

Department of Biological Sciences, Kangwon National University, Chuncheon 24341, South Korea

(c) The Author(s). 2020 Open Access This article is licensed under a Creative Commons Attribution 4.0 International License, which permits use, sharing, adaptation, distribution and reproduction in any medium or format, as long as you give appropriate credit to the original author(s) and the source, provide a link to the Creative Commons licence, and indicate if changes were made. The images or other third party material in this article are included in the article's Creative Commons licence, unless indicated otherwise in a credit line to the material. If material is not included in the article's Creative Commons licence and your intended use is not permitted by statutory regulation or exceeds the permitted use, you will need to obtain permission directly from the copyright holder. To view a copy of this licence, visit http://creativecommons.org/licenses/by/4.0/. 


\section{Background}

In 1960, 42\% (2.2 million ha) of the forest area in South Korea was unstocked, of which 19\% (0.52 million ha) was denuded (Lee et al. 2010). The average growing stock was only $10.9 \mathrm{~m}^{3} \mathrm{ha}^{-1}$ in 1972 (Lee et al. 2010; KFS 2018). Historical events such as Japanese colonial exploitation and the Korean War are often pointed out as the major causes of deforestation (e.g., Chun 1999; Chun et al. 2007). However, already in 1910, forests in South Korea covered only $20 \%$ area of the country. Most of the mature forests were then distributed in North Korea (Bae and Kim 2019). Therefore, the devastation of the forest would have been attributed to overexploitation of the forests for fuelwood due to long human history, high population density, and cold winter rather than historical events (e.g., Choung and Hong 2006; Lee 2010). Under such difficult circumstances, it was inevitable to depend on forest resources for fuel, timber, and food (Lim 2010).

By the way, the average growing stock in South Korea increased dramatically to $157.8 \mathrm{~m}^{3} \mathrm{ha}^{-1}$ in 2018 (KFS 2019). This dramatic restoration of the devastated land was due to the implementation of "The First and Second 10-year Forest Development Plan" (from 1973 to 1987) by the government (Chun 1999; Lee 2010). The two key points of this plan were large-scale reforestation and active protection policy. The latter included substitution of fossil fuels for firewood and clearance of slash-and-burn fields. In addition to the government policies, a large part of the rural population moved to cities as a result of urbanization and industrialization during high economic growth (Lee 2010). This led to an enormous reduction in forest use. Finally, human-arrested and denuded forests were released and restoration started (e.g., Lee 1989; Kamada and Nakagoshi 1993; Hong et al. 1995; Fujihara 1996; Toyohara and Fujihara 1998; Choung and Choung 2019).

The once-forested and devastated lands were restored to mainly three forest types in a short time which are Pinus densiflora forests, $P$. densiflora-broadleaved mixed forests, and broadleaved forests (KFRI 2016). The restoration of these forests depended upon preexisting vegetation structures (e.g., species composition, abundance, seed, and sprouting source) and site conditions (moisture and/or nutrients) (Fig. 1). For example, P. densiflora forests were developed where soil condition was harsh with little vegetation, while Quercus species and/or other broadleaved tree-dominated forests were developed where possibly the area had vegetation or sprouting sources.

Of these three types, the area of $P$. densiflora forests was the largest from the 1970s till today (KFRI 2016), which reflects that the $P$. densiflora settlement has been preferred. It is a light-demanding and typical pioneer species which can germinate in large quantities at even extremely denuded places in a short time to form large, single cohort secondary forests (e.g., Nakagoshi et al. 1987; Keeley and Zedler 1998; Beon and Bartsch 2003; Lee 2006; Park et al. 2010).

At least 111 species belong to the genus Pinus. Pinus is considered an evolutionarily successful genus because of its broad and dominated distribution in the Northern Hemisphere (Richardson 1998). Among them, P. densiflora (Korean red pine) is a two-needled pine geographically distributed in East Asia (Korea, Japan, China, and Russia) (Richardson and Rundel 1998; Lee and Yim 2002; Choung and Hong 2006). The Korean Peninsula is the center of distribution with widespread distribution. In Japan, the species is mainly distributed in Western Honshu, except for Hokkaido, and in China, it is

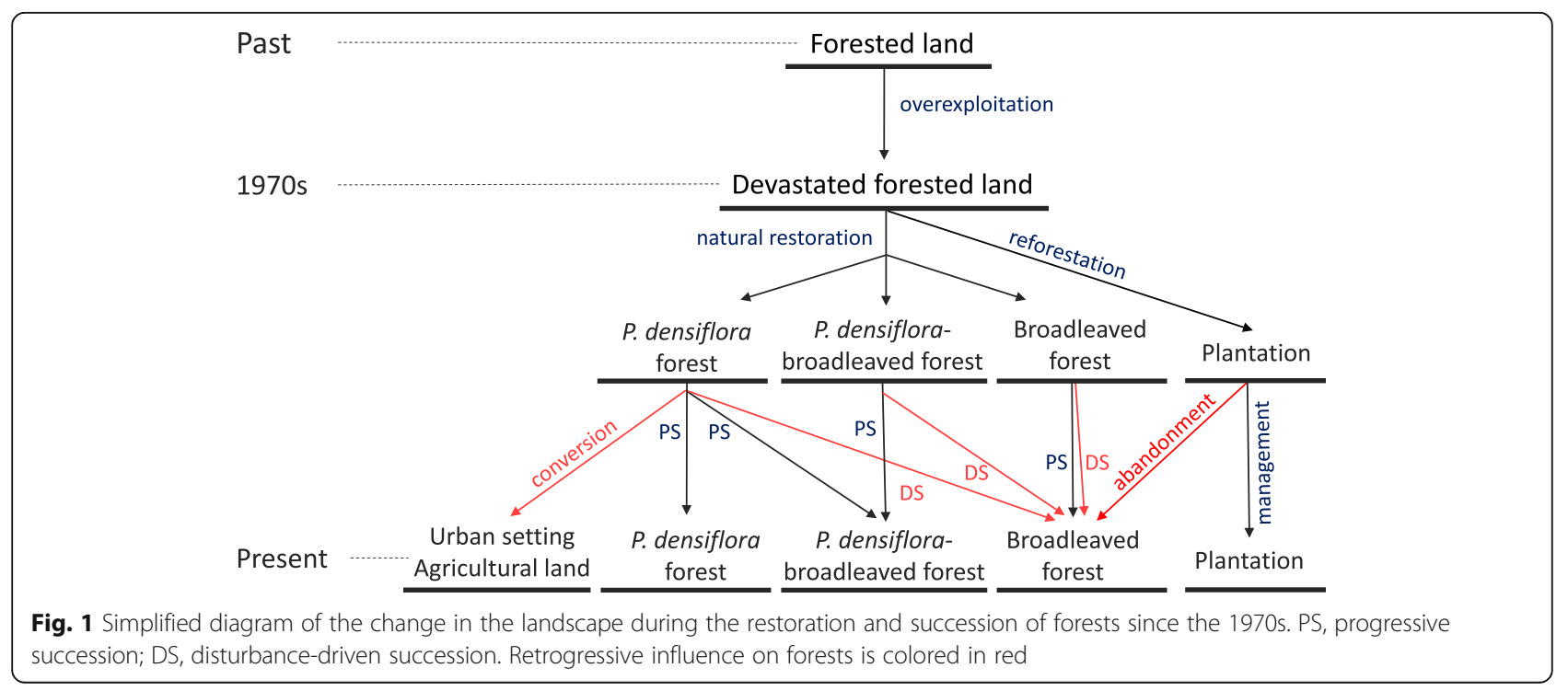


distributed in the north of the Korean Peninsula, such as S Heilongjiang, NE Jiangsu, SE Jilin, Liaoning, and E and N Shandong (http://www.efloras.org/).

The area of the $P$. densiflora forests has decreased rapidly from 28\% (1.76 million ha) in 1992 to 22\% (1.34 million ha) in 2015 (Fig. 2) (KFS 2000; KFRI 2016). By contrast, the areas of the mixed forests and broadleaved forests are increasing (KFS 2019). Although the area is presumed to be the largest since the 1970s, no accurate information is available before 1986. This is because the $P$. densiflora forests were surveyed as a coniferous forest collectively including other coniferous forests and plantations.

As the main causes of the decrease in the $P$. densiflora forests, succession (e.g., Chun 1999; Lim 2010; Lee 2010) or disturbance such as insect pests, diseases, and forest fires (e.g., Lee 1989; Choung et al. 2004; Park et al. 2009; Lim and Korea Forest Research Institute 2010; Lee 2010; KFS 2016; Choung and Choung 2019) has been held responsible. As $P$. densiflora is a pioneer species, succession could be considered as logical causes. However, most forests are young, aged under 50 years (KFS 2019), and the lifespan of $P$. densiflora is typically around 150 years (Lee 1995; KFRI 2011). Therefore, it is unlikely that $P$. densiflora in such young forests had been replaced by the next seral communities. Instead, we can assume that socioeconomic and ecological factors, such as forest conversion, plantation failure, and forest

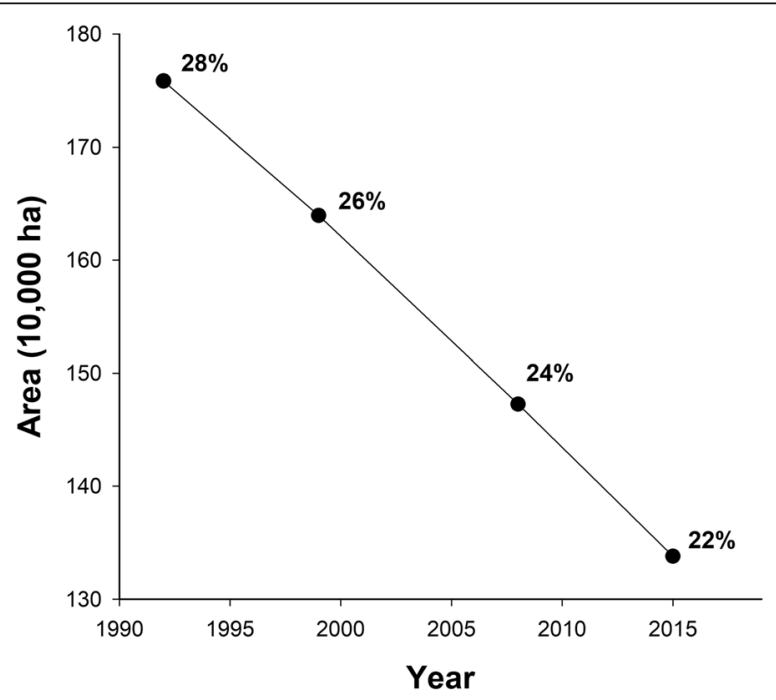

Fig. 2 Changes in the area of $P$. densiflora forests with time in the Republic of Korea. The values in the figure refer to the percent area occupied by $P$. densiflora forests of the total forest area. The area is based on data from 1992 with which forest area occupied by each species was investigated. Data are driven from the national survey on the status of conserved P. densiflora forests (KFS 2000), Statistical Yearbook of Forestry (No. 39) (KFS 2009) and the 6th National Forest Inventory Report (KFRI 2016) disturbance, have been overlooked as the cause, which have changed the landscape of Korean forests in the last few decades (Fig. 1). With the rapid growth of the Korean economy, significant areas of the forests were either developed into cities or converted to farmlands. Since the $P$. densiflora forests were located at low altitudes near cities and towns, it is most likely that they were lost. Another reason could be disturbances, such as pests, diseases, and forest fires, to which the forests were vulnerable, and had a low restoration capacity as well (Choung et al. 2004).

The dramatic increase of the broadleaved forests may be attributed to the conversion of an abandoned plantation. The total reforestation area after the liberation from Japanese occupation until the year 2000 totaled 5.3 million ha ( $83 \%$ of forest area) including fuel forests and re-planted areas (Lee et al. 2010). However, the current reforestation area covers only $15.5 \%$ of the total forest area (NGII 2016). The restoration of failed plantations into broadleaved forests can be commonly observed.

$P$. densiflora is a very preferred tree species in Korea and an important source of timber (Chun 1999). Nonetheless, except for limited areas such as rock outcrop, it is an inevitable natural process that this species is replaced by the next stage species via succession. There are a number of reports on the succession direction surveyed indirectly and/or stated empirically and intuitively at various scales (e.g., Lee and Lee 1989; Choung and Hong 2006; Chun et al. 2007; Cho and Lee 2011). There are only a few direct studies which have repeatedly observed the same area over time; however, the study periods in those research are only for two decades and are limited to local areas (Lee et al. 2005a; Lee et al. 2006; Lee et al. 2012b). Most of the successional series require at least 100 years to reach a climax stage (Barbour et al. 1999). Such a long time scale in studying succession is a serious challenge to the plant ecologists.

In spite of many limitations, it is necessary to tie up the pieces of information and propose integrated succession progress. Therefore, within the $P$. densiflora distribution range in the cool-temperate zone of South Korea, we collected and meta-analyzed direct and indirect data from across the country and then explored the processes of progressive and disturbance-driven succession according to geographical and moisture conditions, which we believe to be the most affecting factors. In the present study, the key seral communities and associated species composition of these processes have been identified, and the potential tree species of the late-successional stage have been proposed as well.

Progressive succession is defined as an increase in directional change in diversity and biomass over time, with habitats becoming moister (Barbour et al. 1999). On the 
other hand, disturbance-driven succession is defined as a directional change through which forests regenerate after undergoing stand-replacing or canopy-remaining disturbances.

\section{Method \\ Meta-analysis 1: Progressive succession of $P$. densiflora forests over time \\ Data collection}

The available research data on direct succession studies conducted in $P$. densiflora forests were collected. We selected only those data where the abundance of $P$. densiflora was over $15 \%$ in the canopy, the strata structure is provided, and the plantation was excluded. Finally, we obtained only 38 stands from 5 sites based on three articles and two databases. The research place and period of each data source are as follows: Mt. Jeombongsan (2002013, 9 years, Lee et al. unpublished), Mt. Odaesan (2005-2015, 11 years, Choung et al. unpublished), Mt. Namsan (1990-2004, 15 years, Lee et al. 2005a), Namhansanseong Fortress (1993-2011, 19 years; 2005-2011, 7 years, Lee et al. 2012b), and Mt. Gayasan (1989-2004, 16 years, Lee et al. 2006). These study forests were estimated between 30 and 60 years old.

\section{Data analysis}

The collected stand data were divided into two communities according to the abundance of $P$. densiflora: one over $70 \%$ as pure stands $(n=24)$ and the other less than $70 \%$ as $P$. densiflora-Quercus mixed stands $(n=14)$. Also, the tree species in the canopy and extended canopy strata were listed as succeeding species in each stand, except for $P$. densiflora. The "Canopy stratum (C)" represented the tree and subtree strata of each stand, while the "Extended Canopy stratum (EC)" was the addition of a shrub stratum to the "Canopy stratum (C)." Here, the classification of "tree species" was based on the NIBR (species.nibr.go.kr).

In each stand, the tree species of $\mathrm{C}$ and $\mathrm{EC}$ were again assigned to one of the three succeeding groups, viz., (1) with only deciduous Quercus species (hereinafter "Quercus only"), (2) with deciduous Quercus and other trees mixed (hereinafter "Quercus \& Others"), and (3) case with only other tree species (hereinafter "Others only"). "Others" include deciduous or evergreen, and broadleaved or coniferous tree species only except for deciduous Quercus species.

Due to the various data source, there were also different ways to measure or calculate abundance. In order to make the data comparable, relative abundance was calculated. For data without any stand age information, we made estimations as Jeon et al. (2017).
Meta-analysis 2: Progressive succession estimated from the strata of $P$. densiflora forests according to geography and moisture condition

Data collection

Information on the vertical structure of $P$. densiflora forests was collected, and succession direction was analyzed. In total, we obtained 229 stand data from 46 cases nationwide (44 published articles and 2 unpublished databases) (Table 1). The stand data with a relative abundance of $P$. densiflora over $15 \%$ in the canopy stratum were selected, and those with planted trees over $50 \%$ were excluded. Only the information from the cooltemperate zone was included, and those from the warmtemperate zone were excluded. In addition, the data from only below $1000 \mathrm{~m}$ in elevation were taken. The forests that were analyzed ranged from tree size of $\mathrm{DBH}$ 20 to $40 \mathrm{~cm}$, which were presumed to be between 30 and 70 years old based on Jeon et al. (2017).

\section{Categorization of forest zone according to geography and moisture condition}

The collected data source covered the cool-temperate zones of the whole nation and included eight provinces (Gangwon-do, Chungcheongbuk-do, Chungcheongnamdo, Gyeonggi-do, Gyeongsangnam-do, Gyeongsangbukdo, Jeollabuk-do, Jeollanam-do) and four metropolitan cities (Seoul, Busan, Incheon, and Gwangju). Also, data from 14 national parks located within the administrative areas listed above were included.

All data were categorized into four zones (two geographical zones and two moisture conditions) based on what the authors provided. The geography was further divided into northern and southern zones following Eom (2019), who newly proposed the forest zone of Korea. Eom (2019) categorized the forest zone into southernsubmontane zone $9 \sim 13{ }^{\circ} \mathrm{C}$, central-montane zone 5.5 9 ${ }^{\circ} \mathrm{C}$, and northern-altimontane zone below $5.5{ }^{\circ} \mathrm{C}$ according to the annual mean temperature. Considering the limitation of the number of data, we categorized $9{ }^{\circ} \mathrm{C}$ or less as the southern zone and above it as the northern zone. The moisture condition of the stands was categorized into mesic and dry in a relative sense. It was mainly based on the authors' descriptions, and if it was not described, then it was assigned based on species composition, micro-topography, vegetation type (NIE 2017), and/or species ecology data book (Choung and Lee 2019).

\section{Data analysis}

The distinction between the canopy and extended canopy strata is the same as those of meta-analysis 1 . Among the total 229 data, there were 223 canopy and 229 extended canopy data as some canopies in the data had only $P$. densiflora with no other trees present. 
Table 1 List of the references cited for meta-analyses 1 and 2

\begin{tabular}{|c|c|c|}
\hline Moisture & Northern zone & Southern zone \\
\hline Mesic & $\begin{array}{l}\text { Back et al. (2013), Jo et al. (1995), Kim and Choo (2005), Kim et al. } \\
\text { (2012), Lee et al. (1994), Lee et al. (1996), Lee et al. (2012C), Noh } \\
\text { et al. (2013), Oh et al. (2005), Oh et al. (2017), Park and Kang (2016) } \\
\text { Park and Oh (2015), Park et al. (1988), Shin et al. (2014), Yoon et al. } \\
\text { (2014) }\end{array}$ & $\begin{array}{l}\text { Ahn and Cho (2000), Choi and Cho (2001), Choi and Cho (2006), } \\
\text { Choi and Cho (2009), Choi et al. (2009), Han et al. (2001), Han et al. } \\
\text { (2014), Kang and Choi (2008), Kang et al. (2012), Kim and Um (2009), } \\
\text { Lee et al. (1995), Lee et al. (2012a), Lee et al. (2013), Lee et al. } \\
\text { (2014a), Oh and Shim (2006), Park and Kang (2016), Park and Oh } \\
\text { (2015), Shin et al. (2014), Yoon et al. (2014) }\end{array}$ \\
\hline Dry & $\begin{array}{l}\text { An and Choo (2010), Cho and Choi (2002), Jo et al. (1995), Kim and } \\
\text { Choo (2005), Kim et al. (1995), Kim et al. (2012), Kim et al. (2017), Lee } \\
\text { et al. (1996), Lee et al. (1997), Lee et al. (2012C), Oh et al. (2005), Park } \\
\text { and Kang (2016), Park and Oh (2015), Shin et al. (2014), Yoon et al. } \\
\text { (2014), }\end{array}$ & $\begin{array}{l}\text { Byeon and Yun (2018), Choi and Cho (2001), Choi and Cho (2006), } \\
\text { Choi and Cho (2009), Choi and Kang (2006), Choi et al. (2009), Choo } \\
\text { et al. (2008), Kang and Choi (2008), Kim and Choi (2004), Kim and } \\
\text { Um (2009), Kim et al. (2006), Lee et al. (2002), Lee et al. (2009b), Lee } \\
\text { et al. (2012a), Lee et al. (2013), Lee et al. (2014a, 2014b), Park et al. } \\
\text { (1989), Park and Kang (2016), Park and Oh (2015), Shin et al. (2014), } \\
\text { Yoon et al. (2014) }\end{array}$ \\
\hline
\end{tabular}

Species with relative abundance over $15 \%$ were considered as the succeeding species. Three types of succeeding groups were considered the same as those in metaanalysis 1 . One thing different, this data set includes $Q$. acuta, an evergreen Quercus tree. As it is distributed only in the southern regions and not in the other forest zones, this species was included as "others" for comparison.

Nonmetric Multidimensional Scaling (NMS) ordination was performed by using species composition of the canopy and extended canopy according to the geographical and moisture conditions (PC-ORD ver. 6, PC-ORD 2011). The relative abundance of succeeding tree species was used, and no transformation was conducted. Species with less than two out of eight data sets were excluded from the analysis.

The number of species was compared according to moisture condition only for the north ( $n=53$ for mesic, $n=58$ for dry) by ANOVA (SPSS ver. 24, SPSS 2017). Data with the same plot size $\left(15 \times 15 \mathrm{~m}^{2}\right)$ was used, and no analysis was done for the south due to the small data size. The number of species in the canopy and extended canopy data was analyzed by pairwise $t$ test (SPSS ver. 24, SPSS INC).

\section{Main text}

Meta-analysis 1: Progressive succession from $P$. densiflora forests over time

The abundance changes of major trees, $P$. densiflora, Quercus, and others, were compared in P. densiflora pure forests and $P$. densiflora-Quercus mixed forests for 7-19 years (Fig. 3). The typical succession was under way in which the abundance of $P$. densiflora decreased while those of Quercus and other species increased.

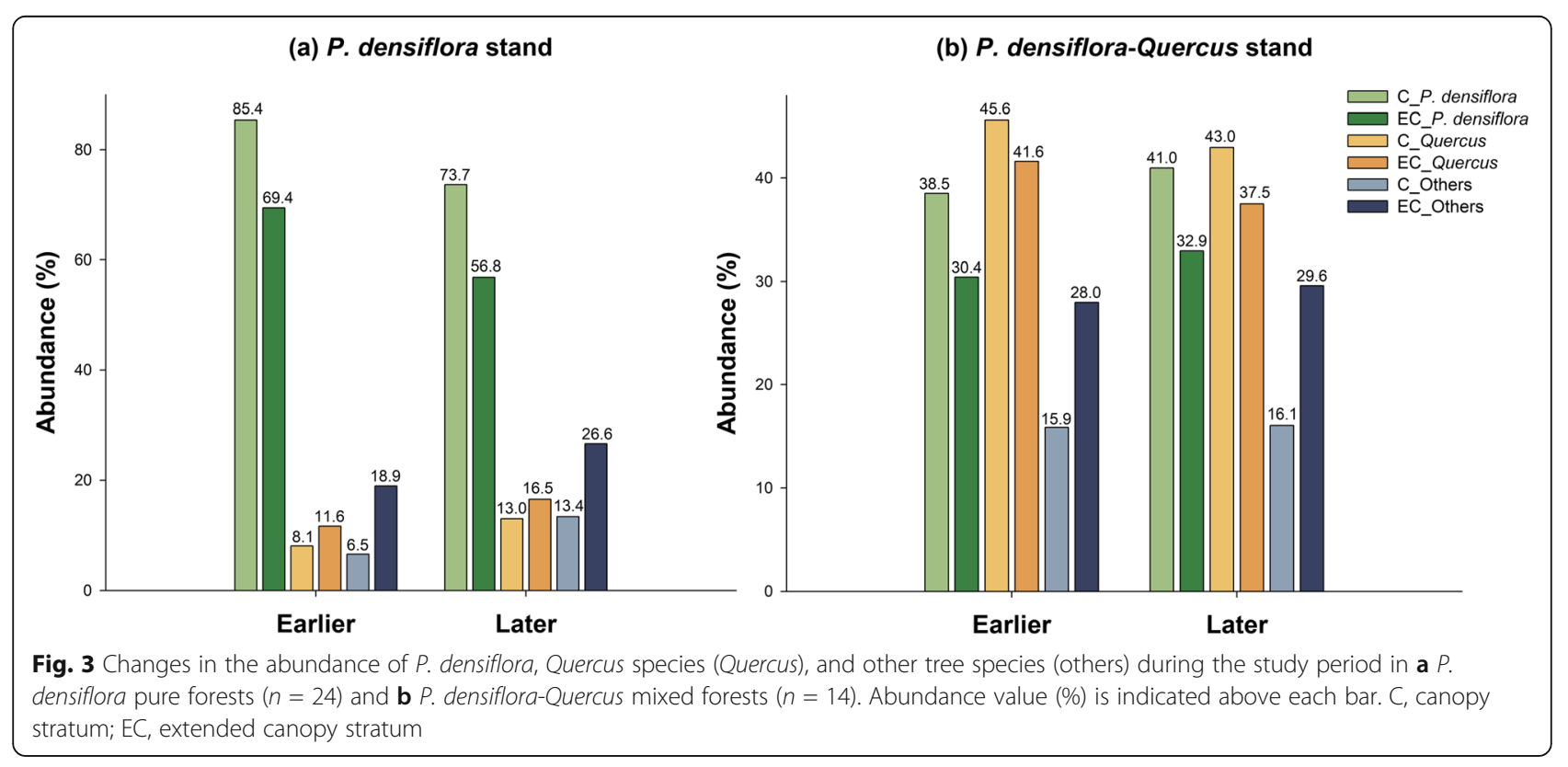


Nevertheless, due to the low mortality of $P$. densiflora, the forest type was not changed.

The mortality rate of $P$. densiflora trees, which were thicker in DBH and of lower density, was only $5 \%$ for 10 years in the forests of Mt. Jeombongsan and Mt. Odaesan (Table 2). On the contrary, the mortalities of Quercus and broadleaved species, whose density was high, were greater due to the effect of density-dependent thinning in the mixed forests (Barbour et al. 1999). The thinner trees in both the forests declined, and the surviving trees, especially Quercus and others, grew better than $P$. densiflora.

The succeeding group was analyzed (Table 3). The initial frequency of the "Quercus only" stand decreased later, common in both forests, while those of the "Quercus \& Others" and "Others only" stands increased later. The change was slight, but it did show the direction of the change clearly. The results were the same for the extended canopy also. The extent of changes was greater in the mixed forests, which are in advanced stages.

On tracking the changes by stand, the species level changes could be identified. Addition of trees such as Carpinus laxiflora, Sorbus alnifolia, and Acer pseudosieboldianum to early "Quercus only" stands resulted in changes to "Quercus \& Others" stands, whereas the Quercus species disappeared from the "Quercus \& Others" stands to become "Others only" stands. This tendency was the same in the extended canopy with the change being larger, particularly when A. pseudosieboldianum was added to the multiple stands of the extended canopy.

Meta-analysis 2: Progressive succession estimated from the strata of $P$. densiflora forests according to geography and moisture condition

The vertical structures of $P$. densiflora forests across the country were analyzed and compared according to geographical and moisture conditions (Fig. 4). "Quercus only" stands showed the highest frequency in the three zones except for the southern mesic zone, and it was followed by "Quercus \& Others" and "Others only" stands in the descending order. The frequency of "Quercus only" stands was lower for the extended canopy than for the canopy, while that for the "Others only" increased. This result was the same as that of the direct succession study.

Comparing the frequency of each succeeding group in the southern and northern regions, that of "Quercus only" stands was markedly high in the latter (Fig. 4a, b), whereas that of the "Quercus \& Others" stands was higher in the southern mesic zone (Fig. $4 \mathrm{c})$. On the other hand, the difference between the mesic and dry stands was large. While the frequency of "Quercus only" in dry stands was two times higher than in the mesic stands (Fig. 4a, c), the frequency of the "Others only" in the mesic stands was eight times higher than that in the dry stands (Fig. 4b, d). That is, $86 \%$ of the mesic stands were in the "Others only" succeeding group. This meant that other species, not Quercus, settled early as the succeeding species in most of the $P$. densiflora forests developed at the mesic sites.

The composition of the succeeding species in the $P$. densiflora forests of the four zones was clearly separated in the NMS ordination space (Fig. 5). The northern and southern zones were separated on axis 1 which accounted for $82.8 \%$ of the total variance, while the mesic and dry sites were separated on axis 2. The Quercus species such as $Q$. mongolica, $Q$. variabilis, and $Q$. dentata dominated in the northern zone, whereas the $Q$. serrata dominated in the southern mesic stands. The difference in species composition in the south and north was due to the species distributed only in the south, such as Styrax japonicus, Carpinus tschonoskii, Q. acuta, Acer palmatum, Lindera erythrocarpa, Stewartia koreana, and P. thunbergii.

Table 2 Tree population dynamics and diameter (DBH) growth in P. densiflora pure forests and P. densiflora-Quercus mixed forests in Mts. Jeombong and Odae during the study period

\begin{tabular}{|c|c|c|c|c|c|c|c|c|}
\hline \multirow[t]{2}{*}{ Stand } & \multirow{2}{*}{$\begin{array}{l}\text { Tree } \\
\text { species }\end{array}$} & \multicolumn{4}{|c|}{ No. of trees $\left(\mathrm{ha}^{-1}\right)$} & \multicolumn{3}{|c|}{$\mathrm{DBH}(\mathrm{SE})(\mathrm{cm})$} \\
\hline & & Total & Survived & Dead & Dead (\%) & Earlier & Later & Dead \\
\hline \multirow[t]{4}{*}{ P. densiflora stand $(n=11)$} & P. densiflora & 454.5 & 436.4 & 18.2 & 4.0 & $28.8(1.1)^{1}$ & $32.4(1.0)$ & $15.9(0.6)$ \\
\hline & Quercus & 225.0 & 213.6 & 11.4 & 5.1 & $11.3(1.1)$ & $13.3(1.2)$ & $9.1(2.4)$ \\
\hline & Others & 365.9 & 352.3 & 13.6 & 3.7 & $9.7(0.3)$ & $11.6(0.3)$ & $8.2(1.6)$ \\
\hline & Total & 1045.5 & 1002.3 & 43.2 & 4.1 & $18.3(0.6)$ & $21.0(0.6)$ & $11.2(1.8)$ \\
\hline \multirow[t]{4}{*}{ P. densiflora-Quercus stand $(n=10)$} & P. densiflora & 182.5 & 172.5 & 10.0 & 5.5 & $33.0(2.5)$ & $38.8(2.6)$ & $12.4(1.9)$ \\
\hline & Quercus & 887.5 & 660.0 & 227.5 & 25.6 & $15.0(0.9)$ & $17.8(0.9)$ & $9.9(0.7)$ \\
\hline & Others & 70.0 & 52.5 & 17.5 & 25.0 & $12.2(2.0)$ & $14.0(2.5)$ & $11.2(2.4)$ \\
\hline & Total & 1140.0 & 885.0 & 255.0 & 22.4 & $17.3(1.0)$ & $20.8(1.1)$ & $10.0(0.6)$ \\
\hline
\end{tabular}

Plot size, $20 \times 20 \mathrm{~m}^{2}$

${ }^{1}$ Mean and standard error are indicated 
Table 3 Changes in the relative frequency of three succeeding groups in $P$. densiflora forests

\begin{tabular}{|c|c|c|c|c|c|}
\hline \multirow[t]{2}{*}{ Stand } & \multirow{2}{*}{$\begin{array}{l}\text { Succeeding } \\
\text { group }\end{array}$} & \multicolumn{2}{|l|}{ Earlier } & \multicolumn{2}{|l|}{ Later } \\
\hline & & C (\%) & EC (\%) & C (\%) & EC (\%) \\
\hline \multirow[t]{3}{*}{ P. densiflora stands $(n=24)$} & Quercus only & 35.0 & 25.0 & 30.0 & 25.0 \\
\hline & Quercus \& Others & 45.0 & 50.0 & 45.0 & 50.0 \\
\hline & Others only & 20.0 & 25.0 & 25.0 & 25.0 \\
\hline \multirow[t]{3}{*}{ P. densiflora-Quercus stands $(n=14)$} & Quercus only & 71.4 & 71.4 & 64.3 & 42.9 \\
\hline & Quercus \& Others & 14.3 & 14.3 & 21.4 & 42.9 \\
\hline & Others only & 14.3 & 14.3 & 14.3 & 14.3 \\
\hline \multirow[t]{3}{*}{ Total $(n=38)$} & Quercus only & 50.0 & 44.1 & 44.1 & 32.4 \\
\hline & Quercus \& Others & 32.4 & 35.3 & 35.3 & 47.1 \\
\hline & Others only & 17.6 & 20.6 & 20.6 & 20.6 \\
\hline
\end{tabular}

C canopy stratum, EC extended canopy stratum

Such difference can be compared in detail by species composition and abundance data of the four zones (Tables 4 and 5). The most predominant species was Quercus species. Especially, it occupies over $80 \%$ of the total abundance in the dry stands and about $50 \%$ in the mesic stands. Q. mongolica was the most frequent and overwhelmingly dominant species in three zones except the southern mesic zone. In particular, in the northern dry zone, the abundance of Q. mongolica exceeded 50\%, while $Q$. variabilis was more dominant in the dry stands
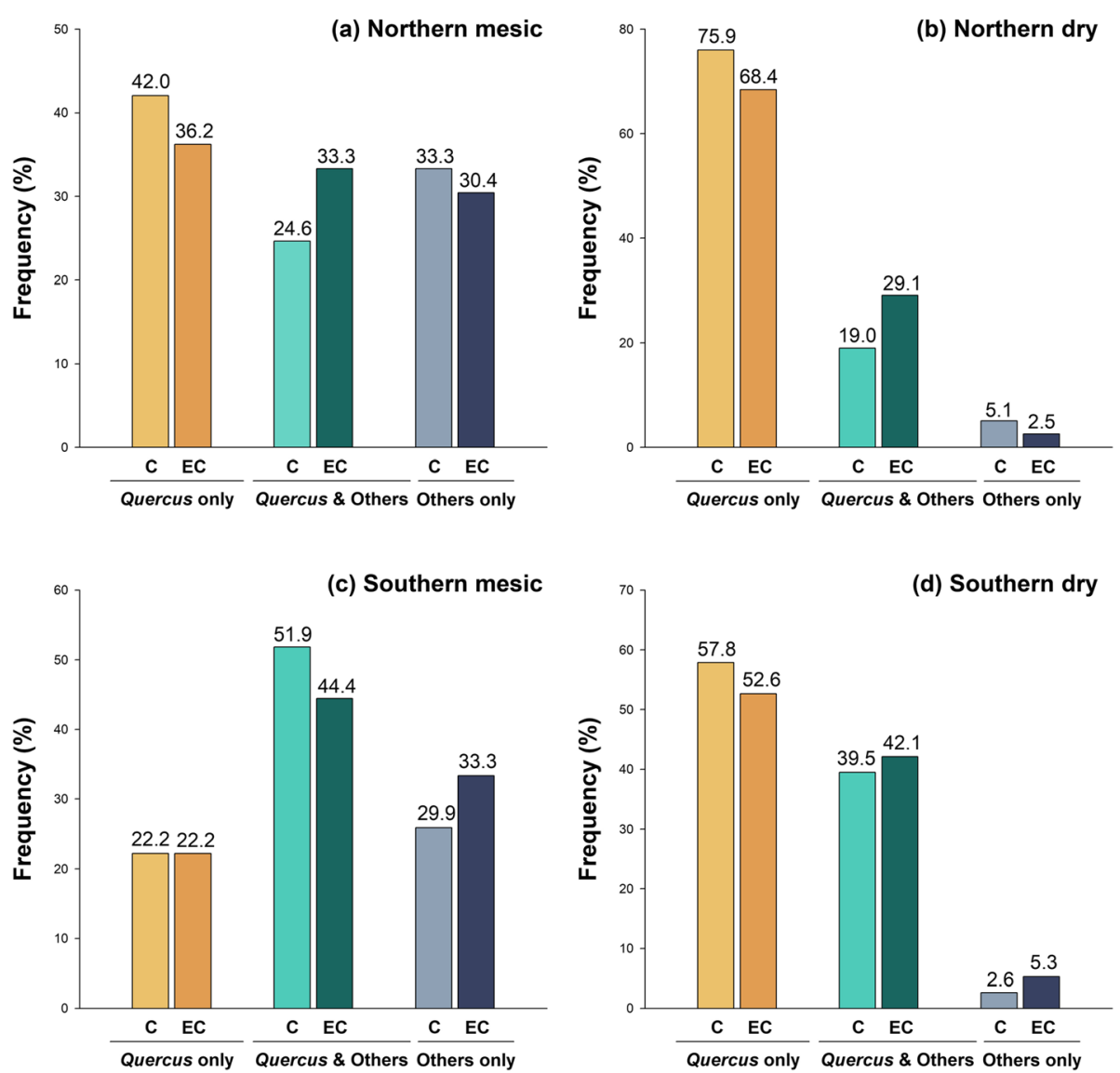

Fig. 4 Frequency of the three succeeding groups ("Quercus only," "Quercus \& Others," and "Others only") in P. densiflora forests according to the geographical and moisture condition $(n=213)$. a Northern mesic forest. b Northern dry forest. c Southern mesic forest. $\mathbf{d}$ Southern dry forest. Frequency is indicated above each bar. C, canopy stratum; EC, extended canopy stratum 


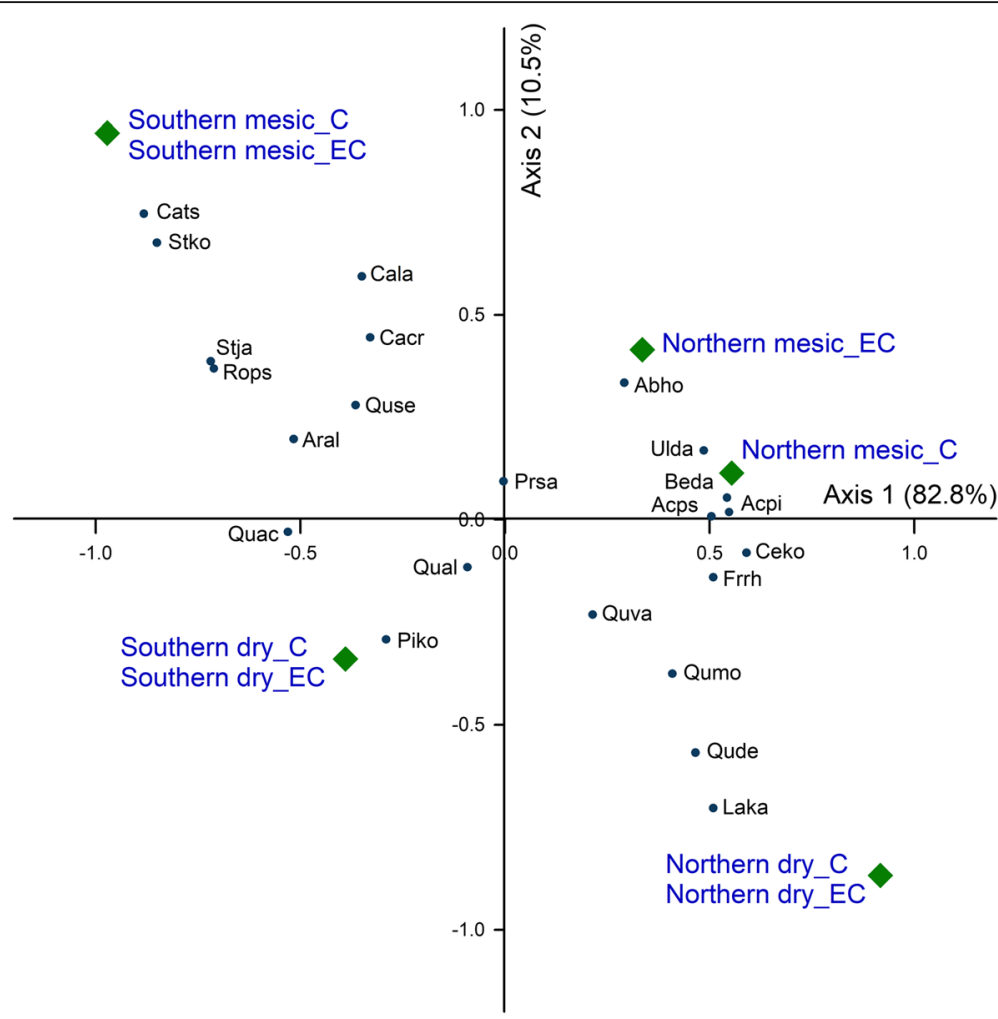

Fig. 5 Nonmetric Multidimensional Scaling (NMS) ordination showing the spatial relationship among the succeeding tree species composition in P. densiflora forests according to the geographical and moisture condition. The number next to the axis represents the variance of each axis relative to the total variance. C, canopy stratum; EC, extended canopy stratum; Abho, Abies holophylla; Acpi, Acer pictum var. mono; Acps, Acer pseudosieboldianum; Aral, Aria alnifolia; Beda, Betula dahurica; Cacr, Castanea crenata; Cala, Carpinus laxiflora; Cats, Carpinus tschonoskii; Ceko, Celtis koraiensis; Frrh, Fraxinus rhynchophylla; Laka, Larix kaempferi; Piko, Pinus koraiensis; Prsa, Prunus sargentii; Quac, Quercus acutissima; Qual, Quercus aliena; Qude, Quercus dentate; Qumo, Quercus mongolica; Quse, Quercus serrata; Quva, Quercus variabilis; Rops, Robinia pseudoacacia; Stja, Styrax japonicas; Stko, Stewartia koreana; Ulda, Ulmus davidiana var. japonica

in both south and north. In contrast to the above two Quercus species, Q. serrata was more frequent in the southern zone and more dominant in the mesic stands. Q. dentata appeared in dry stands, and Q. acutissima and $Q$. aliena were more abundant in the southern dry stands.

F. rhynchophylla among the other species, except for Quercus species, was the most dominant and frequent species, especially in the north. Prunus sargentii appears in similar abundance and frequency in all the four zones. C. laxiflora mainly appears in the mesic stands of the northern and southern zones with greater abundance and frequency in the southern zone. A. pseudosieboldianum and Betula dahurica mainly dominated the northern zone. On the contrary, S. japonicus, C. tschonoskii, $Q$. acuta, and A. palmatum seemed to be the characteristic succeeding species of the southern $P$. densiflora forests as they are distributed only in the southern zone.

There was a little difference in the abundance of $Q$. mongolica between the canopy and extended canopy (Table 5). However, Q. serrata, F. rhynchophylla, A. pseudosieboldianum, and Q. aliena showed the possibility to increase in the future as they had greater abundance in the extended canopy. By contrast, Q. variabilis is predicted to decrease in all the zones.

The number of other broadleaved species in the canopy of mesic stands was three times larger than that in the dry stands (Table 6). The trend was the same in the extended canopy. When the number of species between the canopy and extended canopy was compared, it was not significantly different in mesic stands (Table 7). However, the number of the Quercus species or others was significantly greater in the extended canopy than that in the canopy in the dry stands. This implied that the species which did not exist in the canopy were distributed in the understory in the dry stands, and there is a high possibility of changes in the future.

\section{Disturbance-driven succession from $P$. densiflora forests: acceleration to broadleaved forests}

Direct human influence on forests had decreased greatly since the 1970s. Nonetheless, since then, disturbances, such as insect pests, disease, forest fire, and landslide, 
Table 4 Succeeding tree species composition in the canopy stratum of $P$. densiflora forests according to the geographical and moisture condition

\begin{tabular}{|c|c|c|c|c|c|c|c|c|}
\hline \multirow[t]{2}{*}{ Succeeding tree species } & \multicolumn{2}{|c|}{ Northern mesic $(\%, n=70)$} & \multicolumn{2}{|c|}{ Northern dry $(\%, n=79)$} & \multicolumn{2}{|c|}{ Southern mesic $(\%, n=27)$} & \multicolumn{2}{|c|}{ Southern dry $(\%, n=38)$} \\
\hline & RA & RF & RA & RF & RA & RF & RA & RF \\
\hline Quercus mongolica & 28.7 & 22.4 & 50.7 & 42.8 & 6.5 & 3.3 & 30.3 & 24.7 \\
\hline Quercus variabilis & 15.5 & 13.4 & 26.1 & 25.2 & 13.5 & 18.0 & 19.1 & 22.1 \\
\hline Quercus serrata & 7.2 & 10.4 & 3.6 & 5.0 & 22.8 & 21.3 & 15.4 & 16.9 \\
\hline Fraxinus rhynchophylla & 7.4 & 6.7 & 4.6 & 5.9 & & & 0.7 & 1.3 \\
\hline Prunus sargentii & 5.7 & 3.7 & 3.4 & 3.4 & 4.6 & 3.3 & 3.7 & 3.9 \\
\hline Quercus dentata & 1.6 & 1.5 & 6.5 & 7.6 & & & 4.1 & 2.6 \\
\hline Carpinus laxiflora & 3.4 & 4.5 & 0.9 & 1.7 & 6.9 & 8.2 & & \\
\hline Styrax japonicus & & & & & 10.7 & 9.8 & 7.7 & 7.8 \\
\hline Acer pseudosieboldianum & 3.4 & 5.2 & 1.7 & 3.4 & & & & \\
\hline Carpinus tschonoskii & & & & & 11.8 & 13.1 & 1.9 & 2.6 \\
\hline Quercus acutissima & & & & & 2.7 & 3.3 & 7.0 & 5.2 \\
\hline Betula dahurica & 3.9 & 3.7 & 0.6 & 0.9 & & & & \\
\hline Cornus controversa & 1.8 & 3.7 & & & & & & \\
\hline Quercus aliena & 2.0 & 1.5 & & & & & 4.1 & 3.9 \\
\hline Ulmus davidiana var. japonica & 2.7 & 3.0 & & & & & & \\
\hline Abies holophylla & 2.9 & 3.0 & & & & & & \\
\hline Aria alnifolia & 0.4 & 0.7 & & & 1.8 & 1.6 & 1.7 & 2.6 \\
\hline Juglans mandshurica & 2.3 & 3.0 & & & & & & \\
\hline Castanea crenata & 1.1 & 1.5 & & & 1.1 & 1.6 & 0.7 & 1.3 \\
\hline Celtis koraiensis & 1.3 & 1.5 & 0.2 & 0.9 & & & & \\
\hline Quercus acuta & & & & & 6.3 & 4.9 & & \\
\hline Pyrus ussuriensis & 2.0 & 2.2 & & & & & & \\
\hline Larix kaempferi & & & 0.8 & 1.7 & & & 0.7 & 1.3 \\
\hline Acer pictum var. mono & 1.1 & 1.5 & & & & & & \\
\hline Robinia pseudoacacia & & & & & 1.8 & 1.6 & 0.7 & 1.3 \\
\hline Acer palmatum & & & & & 4.1 & 3.3 & & \\
\hline Maackia amurensis & 1.1 & 1.5 & & & & & & \\
\hline Pinus koraiensis & 0.2 & 0.7 & & & & & 1.2 & 1.3 \\
\hline Populus koreana & 1.4 & 0.7 & & & & & & \\
\hline Betula schmidtii & & & 0.3 & 0.9 & & & & \\
\hline Alnus hirsuta & & & & & & & 0.9 & 1.3 \\
\hline Fraxinus mandshurica & 0.6 & 0.7 & & & & & & \\
\hline Kalopanax septemlobus & 0.7 & 0.7 & & & & & & \\
\hline Alnus japonica & & & & & 1.8 & 1.6 & & \\
\hline Stewartia koreana & & & & & 1.4 & 1.6 & & \\
\hline Tilia amurensis & & & 0.7 & 0.9 & & & & \\
\hline Salix koreensis & 0.8 & 0.7 & & & & & & \\
\hline Pinus thunbergii & & & & & 0.8 & 1.6 & & \\
\hline Lithocarpus edulis & & & & & 1.3 & 1.6 & & \\
\hline Cornus walteri & 0.8 & 0.7 & & & & & & \\
\hline Carpinus cordata & 0.2 & 0.7 & & & & & & \\
\hline Total & 100 & 100 & 100 & 100 & 100 & 100 & 100 & 100 \\
\hline
\end{tabular}

$R A$ relative abundance, $R F$ relative frequency 
Table 5 Comparison of the succeeding tree species composition in the canopy (C) and extended canopy stratum (EC) in P. densiflora forests according to geographical and moisture conditions

\begin{tabular}{|c|c|c|c|c|c|c|c|c|c|}
\hline & \multirow[t]{2}{*}{ Succeeding tree species } & \multicolumn{2}{|c|}{ Northern mesic (\%) } & \multicolumn{2}{|c|}{ Northern dry (\%) } & \multicolumn{2}{|c|}{ Southern mesic (\%) } & \multicolumn{2}{|c|}{ Southern dry (\%) } \\
\hline & & $C(n=70)$ & $\mathrm{EC}(n=73)$ & $C(n=79)$ & $\mathrm{EC}(n=80)$ & $C(n=27)$ & $\mathrm{EC}(n=28)$ & $C(n=38)$ & $\mathrm{EC}(n=39)$ \\
\hline \multirow[t]{7}{*}{ Quercus } & Quercus mongolica & $28.7^{1}$ & 29.5 & 50.7 & 50.5 & 6.5 & 6.5 & 30.3 & 29.9 \\
\hline & Quercus variabilis & 15.5 & 11.4 & 26.1 & 23.5 & 13.5 & 11.6 & 19.1 & 17.1 \\
\hline & Quercus serrata & 7.2 & 10.0 & 3.6 & 4.7 & 22.8 & 25.7 & 15.4 & 14.7 \\
\hline & Quercus dentata & 1.6 & 1.5 & 6.5 & 6.8 & & & 4.1 & 4.4 \\
\hline & Quercus acutissima & & & & & 2.7 & 1.8 & 7.0 & 6.2 \\
\hline & Quercus aliena & 2.0 & 2.6 & & & & & 4.1 & 5.1 \\
\hline & Subtotal & 55.0 & 55.0 & 86.9 & 85.5 & 45.5 & 45.6 & 80.0 & 77.4 \\
\hline \multirow[t]{10}{*}{ Others } & Fraxinus rhynchophylla & 7.4 & 10.4 & 4.6 & 5.6 & & 0.9 & 0.7 & 1.8 \\
\hline & Prunus sargentii & 5.7 & 4.4 & 3.4 & 2.5 & 4.6 & 5.7 & 3.7 & 3.1 \\
\hline & Carpinus laxiflora & 3.4 & 3.1 & 0.9 & & 6.9 & 5.6 & & \\
\hline & Acer pseudosieboldianum & 3.4 & 7.0 & 1.7 & 1.5 & & & & 0.6 \\
\hline & Betula dahurica & 3.9 & 2.5 & 0.6 & 0.6 & & & & \\
\hline & Styrax japonicus & & & & & 10.7 & 9.8 & 7.7 & 7.0 \\
\hline & Carpinus tschonoskii & & & & & 11.8 & 9.8 & 1.9 & 1.8 \\
\hline & Quercus acuta & & & & & 6.3 & 6.3 & & \\
\hline & Acer palmatum & & & & & 4.1 & 4.1 & & \\
\hline & Subtotal & 45.0 & 45.0 & 13.1 & 14.5 & 54.5 & 54.4 & 20.0 & 22.6 \\
\hline Total & & 100 & 100 & 100 & 100 & 100 & 100 & 100 & 100 \\
\hline
\end{tabular}

${ }^{1}$ Relative abundance of the succeeding species is shown. The species is chosen where is $\geq 3 \%$ in any temperate zone and moisture condition

have affected the landscape, and the structure of the forests have been destroyed (Chun 1999; Park et al. 2009; Lim 2010). The damaged area by pests was overwhelmingly large (Park et al. 2009). Especially, pine moth (Dendrolimus spectabilis) and pine needle gall midge (Thecodiplosis japonensis) caused extensive damage, but they are currently under control. These insects selectively killed or weakened $P$. densiflora trees, but the entire stand rarely declined to death.
This phenomenon can rather promote forest succession because it increases the growth of succeeding species such as Quercus or broadleaved species. There are several reports that the forests damaged by insect pests have rapidly restored to broadleaved forests. For example, Lee (1989) reported that the forests damaged by the pine gall midge across the country were restored to Quercus forests within 20 years. In Japan, 25\% (650,000 ha) of $P$. densiflora forests were damaged by pine wilt

Table 6 Number of succeeding tree species along the moisture condition in P. densiflora forests of the northern temperate zone

\begin{tabular}{|c|c|c|c|c|c|c|}
\hline & \multicolumn{3}{|l|}{ Canopy stratum } & \multicolumn{3}{|l|}{ Extended canopy stratum } \\
\hline & No. of species ${ }^{1}$ (mean $\pm \mathrm{SE}$ ) & $F$ & $p$ & No. of species (mean $\pm \mathrm{SE}$ ) & $F$ & $p$ \\
\hline Total & & 13.67 & $<0.01$ & & 6.9 & 0.01 \\
\hline Northern mesic & $1.9 \pm 0.13$ & & & $2.0 \pm 0.12$ & & \\
\hline Northern dry & $1.4 \pm 0.07$ & & & $1.6 \pm 0.08$ & & \\
\hline Quercus & & 2.05 & 0.16 & & 2.00 & 0.17 \\
\hline Northern mesic & $0.9 \pm 0.12$ & & & $1.0 \pm 0.12$ & & \\
\hline Northern dry & $1.1 \pm 0.06$ & & & $1.2 \pm 0.06$ & & \\
\hline Others & & 18.74 & $<0.01$ & & 13.45 & $<0.01$ \\
\hline Northern mesic & $1.0 \pm 0.16$ & & & $1.0 \pm 0.14$ & & \\
\hline Northern dry & $0.3 \pm 0.07$ & & & $0.4 \pm 0.08$ & & \\
\hline
\end{tabular}

${ }^{1}$ Number of plots for northern mesic is 53 , and those for northern dry is 58 (plot size, $15 \times 15 \mathrm{~m}^{2}$ ) 
Table 7 Pairwise $t$ test on the number of succeeding tree species (plot size, $15 \times 15 \mathrm{~m}^{2}$ ) in the canopy and extended canopy strata of the northern $P$. densiflora stands

\begin{tabular}{|c|c|c|c|c|c|c|}
\hline & \multicolumn{3}{|l|}{ Northern mesic $(n=53)$} & \multicolumn{3}{|l|}{ Northern dry $(n=58)$} \\
\hline & No. of species ${ }^{1}$ (mean $\pm \mathrm{SE}$ ) & $t$ & $p$ & No. of species (mean $\pm \mathrm{SE}$ ) & $t$ & $p$ \\
\hline Total & & -0.45 & 0.65 & & -3.24 & $<0.01$ \\
\hline Canopy & $1.9 \pm 0.13$ & & & $1.4 \pm 0.07$ & & \\
\hline Extended canopy & $2.0 \pm 0.12$ & & & $1.6 \pm 0.08$ & & \\
\hline Quercus & & -1.07 & 0.29 & & -2.06 & 0.04 \\
\hline Canopy & $0.9 \pm 0.07$ & & & $1.1 \pm 0.06$ & & \\
\hline Extended canopy & $1.0 \pm 0.07$ & & & $1.2 \pm 0.06$ & & \\
\hline Others & & -0.20 & 0.84 & & -2.21 & 0.03 \\
\hline Canopy & $1.0 \pm 0.09$ & & & $0.3 \pm 0.07$ & & \\
\hline Extended canopy & $1.0 \pm 0.08$ & & & $0.4 \pm 0.08$ & & \\
\hline
\end{tabular}

${ }^{1}$ Number of plots for northern mesic is 53 and those for northern dry is 58 (plot size: $15 \times 15 \mathrm{~m}^{2}$ )

disease (Mamiya 1983), and they have been restored to Q. serrata forests in many areas of southwestern Japan where the damage was extremely severe (Sakamoto et al. 1995; Fujihara 1996; Toyohara and Fujihara 1998; Fujihara et al. 2002).

Forest fires have occurred around 500 times annually since 1970 (KFS 2017). The damage grew larger with an increase in forest growing stocks. The East Coast fire which took place in 2000 had the largest damaged area of 23,794 ha (Ro et al. 2000), and the Goseong fire in 1996 had the 2nd largest damaged area of 3762 ha (KFS and KFRI 1996). Two thirds of the forest fires initiated from the $P$. densiflora forests (Lee et al. 2005b) as they are vulnerable to fire (Seo and Choung 2010; Seo and Choung 2014).

Once burned by stand-replacing fire, the forests retrogressed unlike those damaged by insects and pests. However, they can initiate succession fast with the species having sprouting ability (Vesk and Westoby 2004). To note, $81 \%$ of all prefire species had sprouting ability in the East Coast fire regions (Choung and Choung 2019). It resulted in the restoration to Quercus forests but not to $P$. densiflora forests. Although most were short-term studies, $Q$. serrata trees were regenerated in the burned $P$. densiflora forests in the southern province (e.g., Kim 1983; Kim et al. 1983; Kim and Cho 1984; Cho and Kim 1991; Cho and Kim 1992; Kim et al. 1999). The northern East Coast region, where large forest fires are frequent, had commonly been restored to Q. mongolica- and Q. variabilis-dominated forests (e.g., Mun and Choung 1997; Lee and Hong 1998; Choung et al. 2004; Lee et al. 2004; Lee 2007; Shin 2015). Some extreme sites, poor and dry, such as ridges or shallow erosive soils, were restored to $P$. densiflora-Quercus mixed forests.

This demonstrates that disturbances occurring in $P$. densiflora forests with sprouting understory species succeeded mostly into Quercus forests by skipping over the
P. densiflora-broadleaved mixed stage (Abrams and Scott 1989; Fujihara 1996; Choung and Choung 2019).

Integrated succession process from $P$. densiflora forest We synthesized the succession process of the $P$. densiflora forests based on the results of meta-analysis and literature review (Fig. 6). As mentioned by Finegan (1984), a directional change along three distinct seral communities in the species composition and vegetation physiognomy occurred.

\section{Establishment of the P. densiflora forest}

$P$. densiflora can germinate and settle at denuded sites where mineral soil is exposed and little sprouting source of broadleaved species (Lee and Chung 1998; Lee 2006; Lim 2010; Park et al. 2010). The P. densiflora grows slowly and takes 5 to 10 years to grow up to 2 to $3 \mathrm{~m}$ high. However, later, it grows exponentially and forms a cohort monospecific stand (Park et al. 2010). The abandoned fields in Jinbu, Gangwon province, took about 20 to 30 years to develop into $P$. densiflora forests (Lee 1995c; Lee 2006).

The $P$. densiflora forests still cover the largest area as a single species-dominated stand even though its area is decreasing (Fig. 2; KFRI 2016). This means that the settlement of $P$. densiflora in the 1970s was the preferred environment. In meta-analysis 1 , as a result of 7-19 years of succession in the $P$. densiflora forests of 30-60 years of age, the physiognomy of $P$. densiflora forests and $P$. densiflora-broadleaved mixed forest remained unchanged during this period. It is because the mortality rate of $P$. densiflora was low. Quercus and other species grew throughout density-dependent thinning. Lee et al. (1998) predicted that $P$. densiflora forests would be maintained in Mt. Seoraksan for a considerable period of time. 


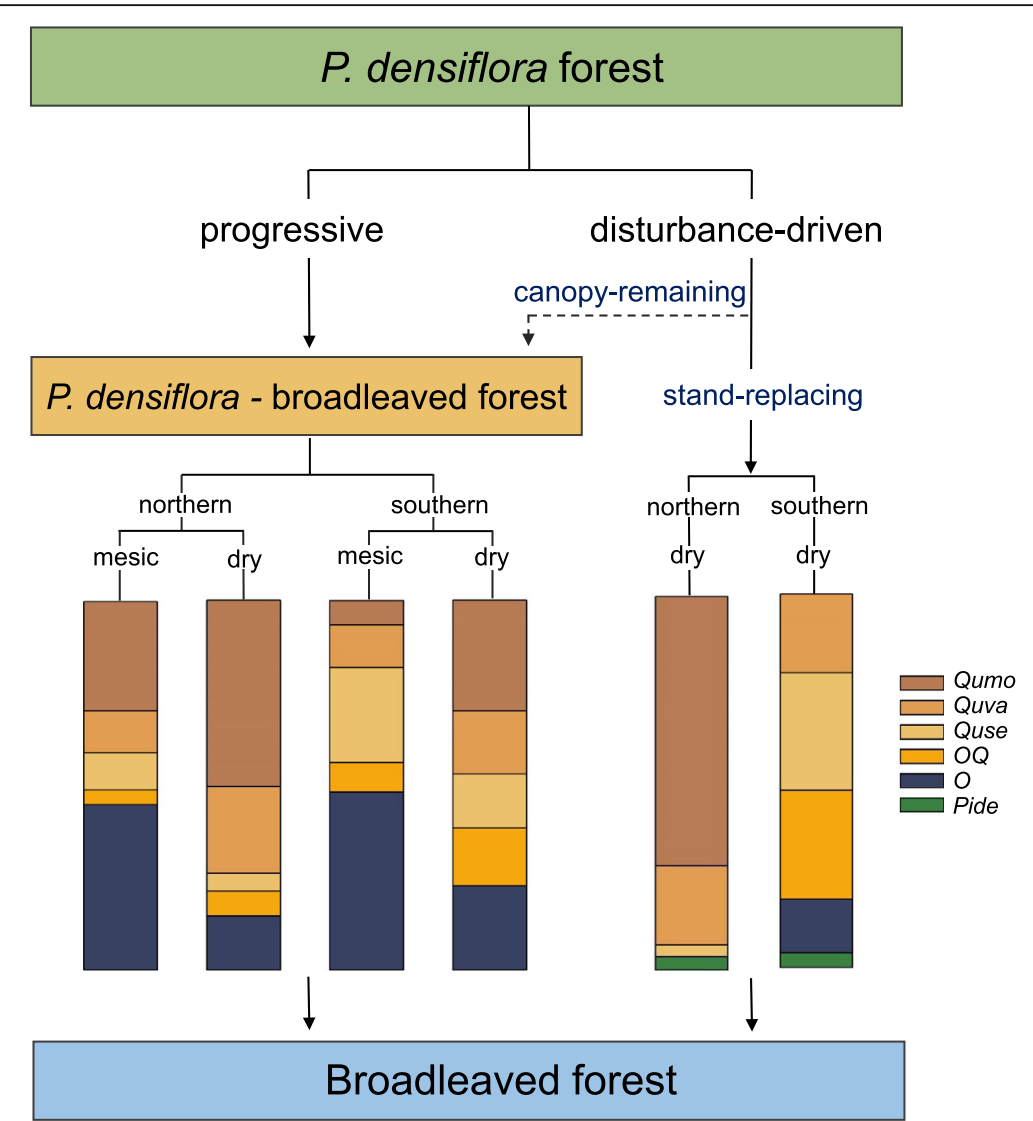

Fig. 6 Schematic diagram of the progressive and disturbance-driven succession process in the cool-temperate $P$. densiflora forest. Stacked bar graphs indicate the composition (the relative abundance) of succeeding tree species or succeeding groups. The four stacked bars from the left were drawn from the meta-analysis data 2 for this study. The fifth bar was drawn from a forest that had been restored for 20 years after a standreplacing fire (East Coast fire occurred in 2000) from the prefire P. densiflora forests, Samcheok, Gangwon province (Choung et al. unpublished). The sixth bar was drawn from a forest that had been restored for 5 years after a stand-replacing fire (occurred in 1986) from prefire $P$. densiflora forest, Daegu-si (Cho and Kim 1991). "Canopy remaining disturbance" is less severe than "stand-replacing disturbance" and refers to the state in which canopy stratum remains even after disturbance. O, other broadleaved species except for Quercus species; OQ, other Quercus species except for three Quercus species (Qumo, Quva, and Quse); Pide, Pinus densiflora; Qumo, Quercus mongolica; Quse, Quercus serrata; Quva, Quercus variabilis

\section{Succession to $P$. densiflora-broadleaved mixed forest: mainly P. densiflora-Quercus mixed forest}

Since $P$. densiflora is shade-intolerant, relatively tolerant Quercus species and/or other tree species settled as succeeding species underneath (Higo et al. 1995; Beon and Bartsch 2003). A series of processes such as thinning and formation of forest gap are typical processes in which $P$. densiflora forests were changed to $P$. densiflora-broadleaved mixed forests. Since the most mature $P$. densiflora grows slowly, whereas the young Quercus and other species grow fast, the latter species eventually replace the $P$. densiflora. Kato and Hayashi (2006) observed that Q. mongolica ssp. crispula reached the canopy stratum in P. densiflora forests in about 30 years, and as a result, $P$. densiflora began to die under competitive pressure.

Our meta-analysis 2 revealed that the composition of the succeeding species differed depending on the geography and moisture condition of the stands. Among them, the deciduous Quercus species, such as Q. mongolica, $Q$. serrata, and Q. variabilis, were surprisingly widely distributed and predominant. In particular, the relative abundance of Quercus species was over $80 \%$ in the southern and northern dry stands and about $50 \%$ in the mesic stands, suggesting that it is the exclusive succeeding genus of $P$. densiflora forests. Therefore, the next stage of $P$. densiflora forests is $P$. densiflora-Quercus mixed forests in most of the stands. However, in some mesic stands, other broadleaved species without Quercus appeared as the succeeding species. This means that in the mesic stands, succession to broadleaved forest can proceed faster by passing through the Quercus stage.

\section{Succession to early broadleaved forest: Quercus-dominated forest and Quercus-broadleaved forest}

The natural death of $P$. densiflora in $P$. densiflora-broadleaved mixed forests should lead to broadleaved forests 
(Fig. 6). Unlike the previous two seral stages, more tree species co-dominate in this stage. Depending upon the distribution and abundance of mainly the Quercus species, the physiognomy and the duration of this stage will vary (e.g., Quercus-dominated forests, Quercus-broadleaved forests, and/or broadleaved forests).

In dry or disturbed stands, the early forests will mainly be Quercus dominated in the canopy with several broadleaved species of low abundance. Since most of the mountain slopes and ridges are relatively dry, this forest type should sustain over a large area for a long time. In the long-term, however, as forests are preserved and sites develop in a more fertile and mesic direction ("mesophication"; Nowacki and Abrams 2008), the Quercus species will coexist with other broadleaved species.

On the other hand, in the mesic or moist stand, our meta-analysis 2 revealed that the Quercus species either did not exist or was just present in low abundance. Therefore, the late-successional species can settle earlier in the mesic or moist stand than in the dry ones. These mesic or moist stands are only a valley or lower parts of mountains, so the area is small.

\section{Late-successional broadleaved forest: climax community}

The species composition of late-successional forests has long been the subject of interest (Lee 2011). Latesuccessional forest refers to the forests with minor fluctuating changes in structure but little change in species composition after the current $P$. densiflora forests go through the process in a series of predicted directions (Barbour et al. 1999). Considering the young age of the current forests and the life span of Quercus species, which is presumed to be a few hundred years, it is estimated that it will take a considerable time to reach the late-successional forest (KFRI 2011).

The composition of the tree species in the latesuccessional forests will depend on the characteristics of the species, such as distributional potential, life span, dispersal opportunity, and/or site conditions. We suggest some potential tree species according to the geography, elevation, and moisture condition (Fig. 7). The major forest types are categorized into two divisions: Quercusbroadleaved forests ("Quercus-Br") and other broadleaved forests ("Broadleaved"). Although the abundance of Quercus species is presumed to decrease over time, the said abundance would sustain for quite a long time, considering the current abundance and longevity of the species, and slow change in the site condition. Q. mongolica in the north and both Q. serrata and Q. mongolica in the south are the representative species of the forests. Q. serrata is widely distributed in both dry and mesic stands in the south (Lee and Lee 1989; Choung et al. 2000; Choung and Hong 2006; Chun et al. 2007; Cho and Lee 2011).
By contrast, in the moist or mesic stands of the lowlands of the south and north, multiple species such as $C$. laxiflora, Q. serrata, Cornus controversa, Juglans mandshurica, Carpinus cordata, Fraxinus rhynchophylla, Fraxinus mandshurica, A. pseudosieboldianum, Acer pictum var. mono, P. sargentii, C. tschonoskii, S. japonicus, and $A$. palmatum constitute the coexisting broadleaved forests. Of these, the last three species are distributed only in the south to characterize the influence of geography.

Krestov et al. (2006) and Cerny et al. (2015) stated that Q. mongolica forests are the core of cool-temperate forests in Korea. Many studies on Mts. Bukhansan (Lee 1997), Odaesan (Byun et al. 1998; Choi et al. 2014), Sobaeksan (Lee et al. 1993), Weoraksan (Lee et al. 2015a; Lee et al. 2015b), Deogyusan (Oh et al. 2013; Choi et al. 2013a; Choi et al. 2013b), Naejangsan and Seonunsan (Kim and Yim 1987; Kim and Yim 1988), and Mudeungsan (Kim et al. 1994) indicated Q. mongolica as the "climax species" throughout the whole region or in the high elevation slopes. Even though Q. mongolica is distributed all over the country, it is more predominant in the dry stands as we found in meta-analysis 2. While in the mesic and moist stands, it has a low abundance or is not presented. Even in the dry stands, regeneration of Q. mongolica was slow, and other broadleaved occupy the understory stratum (Lee 2015). As the succession progresses, the site becomes more fertile and moister (Barbour et al. 1999; Nowacki and Abrams 2008). Such conditions would reduce the current dominance of the genus Quercus and become co-dominant with the other broadleaved trees.

C. laxiflora has also been frequently suggested as a climax species. For example, studies on Mt. Bukhansan (Lee 1997), Namhansanseong (Lee et al. 2012b), Mt. Sobaeksan (Lee et al. 1993), Mt. Songnisan (Lee et al. 2009a), Mt. Deogyusan (Oh et al. 2013; Choi et al. 2013b), Mt. Naejangsan and Mt. Seonunsan (Kim and Yim 1987; Kim and Yim 1988), and Mt. Gayasan (Park et al. 1989; Lee et al. 2006) have stated it as climax species. It may form a monospecific stand in a particular small-scale location. However, it is commonly observed to form forests with F. mandshurica, J. mandshurica, C. controversa, and F. rhynchophylla in valley forests or lower mountain slopes (Lee 2015; Choung and Lee 2019).

In meta-analysis 2, C. laxiflora appeared in the mesic stands in the north and south and was relatively more abundant in the southern mesic stands. Here, however, the abundance of $C$. laxiflora was lower than those of the Q. serrata and Q. variabilis, as well as C. tschonoskii. Even in an extended canopy, it has not increased, so it is unlikely that it will increase in the future. Therefore, we have not found any ground to consider it as a 

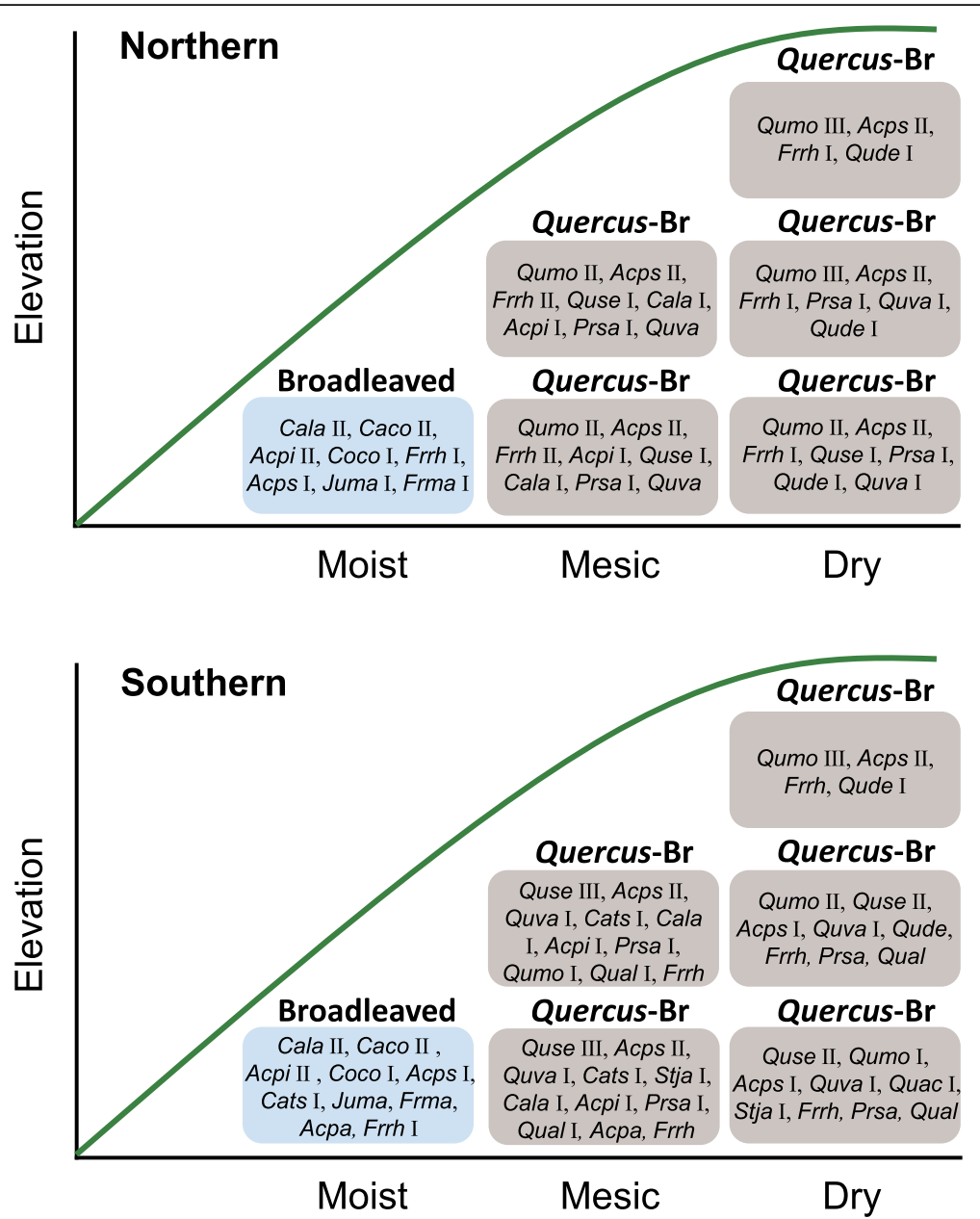

Fig. 7 Potential late-successional tree species, which succeeded from P. densiflora forests, along geographical, elevation, and moisture gradient in cool-temperate forests. I III after species name indicate the relative abundance among tree species while ones without it means less abundant. Quercus-Br, Quercus-broadleaved forest; Broadleaved, broadleaved forest; Acpa, Acer palmatum; Acpi, Acer pictum var. mono; Acps, Acer pseudosieboldianum; Caco, Carpinus cordata; Cala, Carpinus laxiflora; Cats, Carpinus tschonoskii; Coco, Cornus controversa; Frma, Fraxinus mandshurica; Frrh, Fraxinus rhynchophylla; Juma, Juglans mandshurica; Prsa, Prunus sargentii; Quac, Quercus acutissima; Qual, Quercus aliena; Qude, Quercus dentata; Qumo, Quercus mongolica; Quse, Quercus serrata; Quva, Quercus variabilis; Stja, Styrax japonica

representative species across a wide area. C. laxiflora is sure to be one of the co-dominant species of latesuccessional forests in the northern or southern mesic region.

\section{Conclusions}

As we have intuitively known from observations on nearby plots of different ages, young pioneer $P$. densiflora forests are undergoing progressive succession of the species composition and physiognomy. The process direction of the seral communities is $P$. densiflora cohort forest $\rightarrow P$. densiflora-broadleaved mixed forests $\rightarrow$ broadleaved forests. The time span and species composition of the process would vary depending on the geographical and site conditions. In particular, stand moisture has a decisive effect on the distribution and abundance of the successor of $P$. densiflora. In dry stands, Quercus species are favored occupying over $80 \%$ of the abundance of the succeeding species, suggesting as an overwhelming successor.

Therefore, the process in the dry stands, which covers most of the area, is characterized by a long Quercusdominated stage due to the current dominance and long life span. Therefore, the modified process appears as $P$. densiflora forests $\rightarrow P$. densiflora-Quercus mixed forests $\rightarrow$ Quercus-dominated forests $\rightarrow$ Quercus-broadleaved forests. The $P$. densiflora forests, which have been affected by insects, pests, or forest fires, are often restored to the Quercus-dominated forests after retrogression. Contrary to this, in the mesic stands where Quercus species does not occur or occurs in low abundance, the late-successional species establish and settle earlier.

Eventually, the late-successional stage will stabilize into two forest types, viz., the Quercus-broadleaved 
forest and broadleaved forest in the dry and mesic stands, respectively. The former species composition will be co-dominance of Quercus, and other broadleaved species even though the abundance of Quercus decreases with time. The broadleaved forests will comprise stands composed of a larger number of broadleaved species. The composition of the broadleaved species will vary depending upon the geography, moisture condition, and elevation that limit the distribution of the species. Q. mongolica or C. laxiflora has been referred to as a climax species in a number of studies; however, no such evidence was found in the present study. They will compose late-stage forests as co-dominated species.

Overall, $P$. densiflora forests are changing on the track of progressive succession. As a pioneer, it will be eventually replaced along the succession process, but it is still young and developing. Therefore, we have not found any evidence that the forest area is decreasing due to succession during the recent several decades.

\section{Abbreviations}

ANOVA: Analysis of variance; KFRI: Korea Forest Research Institute; KFS: Korea Forest Service; NGIl: National Geographic Information Institute; NIBR: National Institute of Biological Resources; NIE: National Institute of Ecology

\section{Acknowledgements}

We are deeply grateful to Professor Kyu Song Lee for allowing us to use the data on the P. densiflora forest.

\section{Authors' contributions}

YC designed, reviewed, and wrote the manuscript. JL, SC, and JN analyzed the data and edited the manuscript. All the authors approved the manuscript.

\section{Funding}

Not applicable.

\section{Availability of data and materials}

The data sets during and/or analyzed during the current study are available from the corresponding author on reasonable request.

\section{Ethics approval and consent to participate}

Not applicable.

\section{Consent for publication}

Not applicable.

\section{Competing interests}

The authors declare that they have no competing interests.

Received: 13 May 2020 Accepted: 7 June 2020

Published online: 08 July 2020

\section{References}

Abrams MD, Scott ML. Disturbance-mediated accelerated succession in two Michigan forest types. For Sci. 1989;35(1):42-9.

Ahn HC, Cho HS. The forest community structure and dynamics in Mt. Yeonhwa Provincial Park. J Agric Tech Res. 2000;13:87-95 (In Korean).

An HC, Choo GC. Vegetation structure of the Woongseokbong in the Jirisan (Mt.). Korean J Environ Ecol. 2010;24(5):547-55 (In Korean).

Back SJ, Kang HK, Kim SH. Vegetation structure and management planning of Yongha Gugok in Woraksan National Park. Korean J Environ Ecol. 2013;27(4): 487-97 (In Korean).
Bae JS, Kim ES. Understanding forest status of the Korean Peninsula in 1910: a focus on digitization of Joseonimyabunpodo (The Korean Peninsula Forest Distribution Map). J Korean Soc For Sci. 2019;108(3):418-28 (In Korean).

Barbour MG, Burk JH, Pitts WD, Gilliam FS, Schwartz MW. Terrestrial plant ecology. 3rd ed. Menlo Park: Benjamin Cummings, Inc; 1999.

Beon MS, Bartsch N. Early seedling growth of pine (Pinus densiflora) and oaks (Quercus serrata, Q. mongolica, Q. variabilis) in response to light intensity and soil moisture. Plant Ecol. 2003;167(1):97-105.

Byeon SY, Yun CW. Comparison of vegetation structure between natural forest (Pinus densiflora forest and Quercus mongolica forest) and Larix kaempferi forest in Mt. Janggunbong. J Agric Life Sci. 2018;52(4):31-45 (In Korean).

Byun DW, Lee HJ, Kim CH. Vegetation pattern and successional sere in the forest of Mt. Odae. Korean J Ecol. 1998;21(3):283-93 (In Korean).

Cerny T, Kopecky M, Petrik P, Song JS, Srutek M, Valachovic M, Altman J, Dolezal J. Classification of Korean forests: patterns along geographic and environmental gradients. Appl Veg Sci. 2015;18(1):5-22.

$\mathrm{Cho} \mathrm{HJ}$, Lee CB. Vegetation types and diversity patterns of Pinus densiflora forests in South Korea. Jour Korean For Soc. 2011;100(1):118-23 (In Korean).

Cho HS, Choi SH. Plant community structure of the Baekcheon valley in Taebaeksan Area, the Baekdudaegan. Korean J Environ Ecol. 2002;15(4):36978 (In Korean).

Cho YH, Kim W. Early vegetational recovery and species diversity of pine forest after fire in Mt. Todok. Korean J Ecol. 1991;14(1):15-23 (In Korean).

Cho YH, Kim W. Secondary succession and species diversity of Pinus densiflora forest after fire. Korean J Ecol. 1992;15(4):337-44 (In Korean).

Choe B. Management of future-oriented a natural forest through changes of plant community for twenty our years (1988 2012) in Soribong of Kwangnung forest, Korea. PhD Thesis, University of Seoul; 2015. (In Korean).

Choi JW, Kwak JI, Lee KJ, Choi WK. A study for plant community structure and management plan of Pinus densiflora forest in Byeonsanbando National Park. Korean J Environ Ecol. 2009;23(5):447-59 (In Korean).

Choi SH, Cho HS. Analysis on the forest community structure of the area of Donghaksa - Nammaetap, Kyeryongsan National Park. Korean J Environ Ecol. 2001;14(4):252-67 (In Korean).

Choi SH, Cho HS. Vegetation structure of the Dogabsa valley in the Wolchulsan National Park. Korean J Environ Ecol. 2006;20(2):94-102 (In Korean).

Choi SH, Cho HS. Vegetation structure analysis from Naesosa to Naebyeonsan district of the Byeonsan Peninsula National Park. Korean J Environ Ecol. 2009; 23(2):151-60 (In Korean).

Choi SH, Kang HM. Vegetation structure of the Kumsaenggol in the Wolchulsan National Park. Korean J Environ Ecol. 2006;20(4):464-72 (In Korean).

Choi YE, Kim CH, Oh JG. Community distribution on mountain forest vegetation of the Choksangsan area in the Deogyusan National Park, Korea. Korean J Ecol Environ. 2013a;46(3):460-70 (In Korean).

Choi YE, Kim CH, Oh JG, Lee NS. Community distribution on mountain forest vegetation of the Birobong area in the Odaesan National Park, Korea. Korean J Ecol Environ. 2014;47(2):91-102 (In Korean).

Choi YE, Oh JG, Kim CH. Community distribution on forest vegetation of the Hyangjeokbong in the Deogyusan National Park. Korean J Ecol Environ. 2013b;46(2):289-300 (In Korean).

Choo GC, Um TW, Kim GT, Park SB, An HH, Kim NH, Kim HJ. Vegetation structure of mountain ridge from Bukhansansung to Insubong in the Bukhansan National Park, Korea. Korean J Environ Ecol. 2008;22(2):98-105 (In Korean).

Choung HL, Hong SK. Distribution patterns, floristic differentiation and succession of Pinus densiflora forest in South Korea: a perspective at nation-wide scale. Phytocoenologia. 2006;36(2):213-29.

Choung HL, Lee HJ, Lee JS. Syntaxonomy of the forest vegetation and surrounding Taegu, Korea. Korean J Ecol. 2000;23(5):407-21 (In Korean).

Choung Y, Choung MS. Biodiversity of burned forests is controlled by the sprouting ability of prefire species in Pinus densiflora forests. Ecol Eng. 2019; 127:356-62.

Choung Y, Lee BC, Cho JH, Lee KS, Jang IS, Kim SH, Hong SK, Jung HC, Choung HL. Forest responses to the large-scale east coast fires in Korea. Ecol Res. 2004; 19:43-54.

Choung Y, Lee KE. Ecology of common plant species in central Korean forests. Seoul: Nature \& Ecology; 2019

Chun YM, Lee HJ, Hayashi I. Syntaxonomy and syngeography of Korean red pine (Pinus densiflora) forests in Korea. Korean J Environ Ecol. 2007;21(3):257-77.

Chun YW. Forests and Korean culture. Seoul: Book's Hill publishers Co., Inc.; 1999.

Chung SH, Kim JH. The classification of forest types by factor analysis in natural forests of Dutasan. J Agric Life Sci. 2012;46(4):21-30 (In Korean). 
Eom BC. Climatically potential natural vegetation and phytoclimatic map of Korea: PhD Thesis, Keimyung University; 2019. (In Korean).

Finegan B. Forest succession. Nature. 1984;312(5990):109-14.

Fujihara M. Development of secondary pine forests after pine wilt disease in western Japan. J Veg Sci. 1996;7(5):729-38.

Fujihara M, Hada Y, Toyohara G. Changes in the stand structure of a pine forest after rapid growth of Quercus serrata Thunb. For Ecol Manag. 2002;170(1-3): 55-65.

Han BH, Cho W, Lee SD. Plant community structure of Donghaksa valley in Kyeryongsan National Park. Korean J Environ Ecol. 2001;14(4):238-51 (In Korean).

Han BH, Choi JW, Noh TH, Hur JY. The structure of plant community of the Woonsooam valley in Jogyesan (Mt.), Suncheon. Korean J Environ Ecol. 2014; 28(1):45-54 (In Korean).

Higo M, Shinohara A, Kodama S. The regeneration behavior of major component species in the secondary forest dominated by Pinus densiflora and Quercus serrata in central Japan. For Ecol Manag. 1995;76(1-3):1-10.

Hong SK, Nakagoshi N, Kamada M. Human impacts on pine-dominated vegetation in rural landscapes in Korea and western Japan. Vegetatio. 1995; 116(2):161-72.

Jeon JH, Son YM, Kang JT. Characteristics of growth and development of empirical stand yield model on Pinus densiflora in central Korea. Jour Korean For Soc. 2017;106:267-73 (In Korean).

Jo JC, Cho W, Han BH. The plant community structure of Pinus densiflorain forest in Chuwangsan National Park. Korean J Environ Ecol. 1995;8(2):121-34 (In Korean).

Kamada M, Nakagoshi N. Pine forest structure in a human-dominated landscape system in Korea. Ecol Res. 1993;8(1):35-46.

Kang HM, Choi $\mathrm{SH}$. Actual vegetation and vegetation structure of the Bulyeongsa Valley area in Uljin-gun(Gyeungbuk). Korean J Environ Ecol. 2008;22(1):1-10 (In Korean).

Kang HM, Choi SH, Lee SD, Cho HS, Kim JS. Vegetation structure of the Bulguksa Buddhist temple forest in the Gyeongju National Park. Korean J Environ Ecol. 2012;26(5):787-800 (In Korean).

Kato J, Hayashi I. Quantitative analysis of a stand of Pinus densiflora undergoing succession to Quercus mongolica ssp. crispula: 1. A 31-year record of growth and population dynamics of the canopy trees. Ecol Res. 2006;21(4):503-9.

Keeley JE, Zedler PH. Evolution of life histories in Pinus. In: Richardson DM, editor. Ecology and biogeography of Pinus. Cambridge: Cambridge University Press; 1998. p. 219-50.

Kim BG, Um TW. Vegetation structure of the ridge area of Naesosa in the Byunsan Peninsula National Park. Korean J Environ Ecol. 2009;23(2):135-42 (In Korean).

Kim CH, Kang SH, Kil BS. Classification analysis and gradient analysis on the forest vegetation of Mt. Mudung. Korean J Ecol. 1994;17(4):471-84 (In Korean).

Kim DP, Choi SH. Vegetation structure of mountain ridge from Gajisan to Neungdongsan in the Nakdong-jeongmaek. Korean J Environ Ecol. 2004; 18(3):279-87 (In Korean).

Kim GT, Choo GC. Forest structure of the region from Dongchanggyo to Deogjusa in Woraksan National Park, Korea. Korean J Environ Ecol. 2005;19(2): 75-82 (In Korean)

Kim GT, Choo GC, Kim JO. Vegetation structure of mountain the region from Wolgagsan to Dogabjae in Weolchulsan National Park Korea. Korean J Environ Ecol. 2006:20(2):122-9 (In Korean).

Kim GT, Kim JS, Choo GC, Um TW. Studies on the structure of forest community at Wangkoam, Kumunkwangi area in Chuwangsan National Park. Korean J Environ Ecol. 1995;8(2):142-9 (In Korean).

Kim HJ, Shin JK, Lee CH, Yun CW. Community structure of forest vegetation in Mt. Geumsusan belong to Woraksan National Park. Korean J Environ Ecol. 2017;31(2):202-19 (In Korean).

Kim JH, Choi SH, Cho W, Sung CY. Vegetation structure of Pinus densiflora community for conservation and restoration of Tricholoma matsutake - Pine mushroom appearance area in Yangyang-gun, Kangwon-do. Korean J Environ Ecol. 2012;26(5):730-40 (In Korean).

Kim JU, Yim YJ. Actual vegetation and potential natural vegetation of Seonunsan area, Southwestern Korea. Korean J Ecol. 1987;10(4):159-64.

Kim JU, Yim YJ. Actual vegetation and potential natural vegetation of Naejangsan national park, southwestern Korea. Korean J Ecol. 1988;11(3):145-52.

Kim W. The secondary vegetation of the burned area of a mountain in DangjiDong. Korean J Ecol. 1983;6(3):187-97.
Kim W, Cho YH. Revegetation and secondary succession of the burned area in Mt. Sanseung. Korean J Ecol. 1984;7(4):203-7 (In Korean).

Kim W, Park JH, Cho YH. Effects of fire on forest vegetation in Mt. Samma. Korean J Ecol. 1999:22(3):145-53 (In Korean)

Kim W, Suh JH, Ri CU. The early vegetational succession of the burned area in Dangji-Dong. Korean J Ecol. 1983;6(4):237-42 (In Korean).

Korea Forest Research Institute. The 5th national forest inventory report. Seoul: Korea Forest Research Institute; 2011. (In Korean).

Korea Forest Research Institute. The 6th national forest inventory report. Seoul: Korea Forest Research Institute; 2016. (In Korean).

Korea Forest Service. Field survey on Pinus densiflora forests for the conservation. Daejeon: Korea Forest Service; 2000. (In Korean).

Korea Forest Service. Statistical yearbook of forestry (No. 39). Daejeon: Korea Forest Service; 2009. (In Korean).

Korea Forest Service. 2015 Forest basic statistics. Daejeon: Korea Forest Service; 2016. (In Korean).

Korea Forest Service. Forest fire statistics. Daejeon: Korea Forest Service; 2017. (In Korean).

Korea Forest Service. Growing forests together. Daejeon: Korea Forest Service; 2018. (In Korean)

Korea Forest Service. Statistical yearbook of forestry (No. 49). Daejeon: Korea Forest Service; 2019. (In Korean).

Korea Forest Service and Korea Forest Research Institute. Ecological report on Goseong Fire regions. Daejeon: Korea Forest Service and Korea Forest Research Institute; 1996. (in Korean).

Krestov PV, Song JS, Nakamura Y, Verkholat VP. A phytosociological survey of the deciduous temperate forests of mainland Northeast Asia. Phytocoenologia. 2006:36:77-150.

Lee CS. A study on the succession of pine forests damaged by pine gall midge: PhD Thesis, Seoul National University; 1989. (In Korean).

Lee CS. Disturbance regime of the Pinus densiflora forest in Korea. Korean J Ecol. 1995;18(1):179-88 (In Korean).

Lee CS. Regeneration process after disturbance of the Pinus densiflora forest in Korea. Korean J Ecol. 1995b;18(1):189-201 (In Korean).

Lee CS, Hong SK. Changes of landscape pattern and vegetation structure in rural area disturbed by fire. Korean J Ecol. 1998:21(4):389-99.

Lee DK. Korean forests: Lessons learned from stories of success and failure. Korea Forest Research Institute: Seoul; 2010.

Lee DK, Shin JH, Park PS, Park YD. Forest rehabilitation in Korea. In: Lee DK, editor. Korean forests: lessons learned from stories of success and failure. Seoul: Korea Forest Research Institute; 2010. p. 35-57.

Lee EB. Actual vegetation and potential natural vegetation of Pukhansan National Park, mid-western Korea. Korean J Ecol. 1997;20(6):439-50.

Lee HS. Estimation of climax index for deciduous tree species by ecomorphological factors: MS Thesis, Kangwon National University; 2011. (In Korean).

Lee HY, Oh CH, Choi SH, Lee SD. The vegetational characteristics of Bongamsa forest genetic resources reserve area in Mt. Heuyang. Korean J Environ Ecol. 2012a:26(3):382-93 (In Korean).

Lee $J$, Chung DJ. A study on the growth between pine and oak mixed natural forest stands. J Res Kor Stand Res Inst. 1998;19:21-7 (In Korean).

Lee JY, Oh JG, Jang IS, Kim HS. Community distribution on mountain forest vegetation of the Youngbong area in the Worak National Park, Korea. Korean J Ecol Environ. 2015a;48(1):51-60 (In Korean).

Lee JY, Oh JG, Jung SH, Kim HS. Community distribution on mountain forest vegetation of the Geumsusan and Doraksan area in the Worak National Park, Korea. Korean J Ecol Environ. 2015b:48(2):129-38 (In Korean).

Lee K. Classification of forested vegetation and successional development in the central-eastern Korean Peninsula: PhD Thesis, Kangwon National University; 2015. (In Korean)

Lee KJ, Cho W, Han BH. Plant community structure of Pinus densiflora forests in Odaesan National Park. Korean J Environ Ecol. 1996:9(2):115-25 (In Korean).

Lee KJ, Cho W, Hwang SH. Plant community structure for five major valleys in Bukhansan National Park. Korean J Environ Ecol. 1995;9(1):15-29 (In Korean).

Lee KJ, Choi JW, Choi WK, Han BH. Ecological characteristics and change for fifteen years(1989 2004) of plant community structure of the Pinus densiflora S. et Z. forest in Hongrudong valley, Gayasan National Park. Korean J Environ Ecol. 2006:20(2):188-99 (In Korean).

Lee KJ, Choi SH, Cho HS. The analysis of the forest community structure of Huibang Valley in Sobaeksan National Park. Korean J Environ Ecol. 1993;6(2): 113-26 (In Korean) 
Lee KJ, Choi SH, Cho HS, Lee YW. The analysis of the forest community structure of Tokyusan National Park -case study of Paekryunsa - Kumpotan. Korean J Environ Ecol. 1994;7(2):135-54 (In Korean).

Lee $\mathrm{K}$, Han BH, Lee HG, Noh TH. Management planning and change for nineteen years (1993 2011) of plant community of the Pinus densiflora S. et Z. forest in Namhan mountain fortress, Korea. Korean J Environ Ecol. 2012b;26(4):559-75 (In Korean).

Lee $\mathrm{K}$, Han BH, Lee OH. Vegetation structure analysis and ecological distance of Pinus densiflora community in Chayang-Chon area, Soraksan National Park. Korean J Environ Ecol. 1998;11(4):493-505 (In Korean).

Lee KJ, Ki KS, Choi JW. Vegetation succession and vegetation management of the Pinus densiflora S. et Z. forest in the Beopjusa area, Songnisan National Park. Korean J Environ Ecol. 2009a;23(2):208-19 (In Korean).

Lee KJ, Kim JH, Han BH. Plant community structure and ecological density of Pinus densiflora for. eracta community in Chunyang, Kyeongsangbuk-do. Korean J Environ Ecol. 2002;15(4):379-93 (In Korean).

Lee KJ, Kim JH, Han BH. Ecological characteristics and change for fifteen years (1990 2004) of plant community structure of the Pinus densiflora S. et Z. forest in Namsan, Seoul. Korean J Environ Ecol. 2005a;19(3):312-26 (In Korean).

Lee KJ, Kwak Jl, Kwak NH, Jang JS. Plant community structure of Pinus densiflora S. et Z. forest in the Geumjeongsan (Mt.), Busan Metropolitan City. Korean J Environ Ecol. 2013;27(4):462-72 (In Korean).

Lee KJ, Min SH, Han BH. Plant community structure analysis in Jujeongol Valley of Soraksan National Park. Korean J Environ Ecol. 1997;10(2):283-96 (In Korean).

Lee KS. Seral changes in floristic composition during abandoned field succession after shifting cultivation. Korean J Ecol. 1995c;18(2):275-83.

Lee KS. Changes of species diversity and development of vegetation structure during abandoned field succession after shifting cultivation in Korea. J Ecol Environ. 2006;29(3):227-35.

Lee KS, Choung Y, Kim SC, Shin SS, Ro CH, Park SD. Development of vegetation structure after forest fire in the east coastal region, Korea. Korean J Ecol. 2004;27(2):99-106 (In Korean)

Lee S, Kang H, Kim J, Yu C, Choi S. A study on the correlation between plant community and environmental factors of Tongdosa (Temple) area, Gajisan (Mt.), Provincial Park. Korean J Environ Ecol. 2014a;28(6):715-24 (In Korean).

Lee SC, Kang HM, Choi SH, Hong SH, Lee SD, Cho W, Kim JS. Actual vegetation and plant community structure of Tohamsan (Mt.) wetland area of the surroundings in Gyeongju National Park, Korea. Korean J Environ Ecol. 2014b; 28(1):33-44 (In Korean).

Lee SD, Hong SH, Kim JS. Plant community structure of Daetjae (hill) Baekbongryung (ridge), the Baekdudaegan mountain. Korean J Environ Ecol. 2012c;26(5):719-29 (In Korean)

Lee SD, Lee KJ, Choi JW. Management plan to consider ecological characteristic of Pinus densiflora community in Seoul. Korean J Environ Ecol. 2009b;23(3): 258-71 (In Korean).

Lee SY, Won MS, Han SY. Developing of forest fire occurrence danger index using fuel and topographical characteristics on the condition of ignition point in Korea. Trans Korean Inst Fire Sci Eng. 2005b;19:75-9 (in Korean).

Lee WC, Yim YJ. Plant geography with special reference to Korea. Kangwon: Kangwon National University Press; 2002.

Lee WT, Lee CH. Plant sociological studies on the Pinus densiflora forest in Korea. Korean J Ecol. 1989;12(4):257-84 (In Korean).

Lee $Y$. Vegetation regeneration for ten years following Goseong forest fire: MS Thesis, Kangwon National University; 2007. (In Korean).

Lim JH. Vegetation changes and disturbances in Korea. In: Korea Forest Research Institute, editor. Forest eco-atlas of Korea. Seoul: Korea Forest Research Institute; 2010. p. 20-3.

Mamiya Y. Pathology of the pine wilt disease caused by Bursaphelenchus xylophilus. Annu Rev Phytopathol. 1983;21:201-20.

Mun HT, Choung Y. Species composition and nutrient absorption by plants in the immediate postfire year. Korean J Ecol. 1997;20:27-33 (in Korean with English abstract).

Nakagoshi N, Nehira K, Takahashi F. The role of fire in pine forests of Japan. In: Trabaud L, editor. The role of fire in ecological systems. The Hague: SPB Academic Publishing; 1987. p. 91-119.

NGII. The National Atlas of Korea II. Gyeonggi: National Geographic Information Institute; 2016

NIE. 4th National ecosystem survey guidelines. Seocheon: National Institute of Ecology; 2017. (In Korean).

Noh TH, Han BH, Kim JY, Lee MY, Yoo KJ. Actual vegetation and structure of plant community in Daegwallyeong ranch, Gangwon-do (Province). Korean J Environ Ecol. 2013;27(5):579-91.
Nowacki GR, Abrams MD. The demise of fire and "mesophication" of forests in the eastern United States. BioScience. 2008;58(2):123-38.

Oh HY, Kang HK, Kim MS, Back SJ, Hong JK. Vegetation structure and management planning on the historical landscape of Pinus densiflora forest in Guryong Valley, Chiak National Park. J Korean Env Res Tech. 2017;20(6):117-31 (In Korean).

Oh JG, Kim CH, Lee NS, Gin YR. Community distribution on forest vegetation of the Geochilbong area in the Deogyusan National Park, Korea. Korean J Ecol Environ. 2013:46(3):449-59 (In Korean).

Oh KK, Choi SH, Kim SH, Choi WK. Analysis of the forest community structure at Woraksan National Park -case study of Yeongbong and Doraksan region. Korean J Environ Ecol. 2005;19(2):90-8 (In Korean).

Oh KK, Shim HY. Distribution and population structure of evergreen broad-leaved forest in the Wolchulsan National Park. Korean J Environ Ecol. 2006;20(2):81-93 (In Korean).

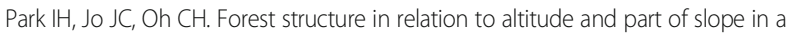
valley and a ridge forest at Mt. Gaya area. Korean J Environ Ecol. 1989:3(1):42-50 (In Korean).

Park IH, Lee KJ, Jo JC. Structure of forest communities in Chiak Mountain National Park - case study of Guryong temple - Birobong area. Korean J Environ Ecol. 1988;2(1):1-8 (In Korean).

Park PS, Kim KY, Han A, Jang W, Son Y, Yi MJ, Park BB, Son Y. Development processes and growth pattern of Pinus densiflora stands in central eastern Korea. J Plant Res. 2010;123(4):453-62.

Park PS, Lee KH, Jung MH, Shin H, Jang W, Bae K, Lee J, Lee DK. Changes in forest disturbance patterns from 1976 to 2005 in South Korea. Jour Korean For Soc. 2009;98(5):593-601.

Park SG, Kang HM. Characteristics of vegetation structure in the ridgeline area of the Nakdong-Jeongmaek. Korean J Environ Ecol. 2016;30(3):386-98 (In Korean).

Park SG, Oh KK. The types and structures of forest vegetation on the ridge of the jeongmaeks in South Korea. Korean J Environ Ecol. 2015;29(5):753-63 (In Korean).

PC-ORD. Multivariate analysis of ecological data, version 6. Gleneden Beach: MjM Software; 2011

Richardson DM. Ecology and biogeography of Pinus. Cambridge: Cambridge University Press; 1998.

Richardson DM, Rundel PW. Ecology and biogeography of Pinus: an introduction. In: Richardson DM, editor. Ecology and biogeography of Pinus. Cambridge: Cambridge University Press; 1998. p. 3-46.

Ro DK, Gong JS, Lee SH, Kim CM, Kim JC, Seo SA, Paek JH, Kim SH, Sim WB, Son YM, Lee WK. Damage of forests in the East Coast Fires. In: The Joint Association for the Investigation of the East Coast Fires, Editors. Report of the East Coast Fires in 2000 (I). Seoul: The Joint Association for the Investigation of the East Coast Fires; 2000. p. 27-9. (in Korean).

Sakamoto K, Fujikawa N, Chiba K, Yoshikawa K. Stand structure and dynamics of Pinus densiflora forests damaged by pine wilt disease in the southern part of Okayama prefecture. J Jap Soc Reveget Tech. 1995;21(1):18-28.

Seo H, Choung Y. Enhanced vulnerability to fire by Pinus densiflora forests due to tree morphology and stand structure in Korea. J Plant Biol. 2014;57:48-54.

Seo $\mathrm{H}$, Choung Y. Vulnerability of Pinus densiflora to forest fire based on ignition characteristics. J Ecol Field Biol. 2010;33(4):343-9.

Shin HS, Shin JK, Kim HJ, Han SH, Lee WH, Yun CW. Characteristics of community structure for forest vegetation on Manisan, Ganghwado. KJAFM. 2014;16(1):11-21 (in Korean)

Shin JK, Byeon JG, Yun CW, Koo BY, Kim HG, Kim IS, Kim DK. Forest community classification and vegetation structure in National Yonghyeon Natural Recreation Forest. Korean J Environ Ecol. 2017;31(2):220-9 (in Korean).

Shin YS. Natural regeneration of forests with different burn severity and initial regeneration following forest fire in the East Coast region, Korea: PhD Thesis, Kangwon National University; 2015. (in Korean).

SPSS. IBM SPSS statistics for windows, version 24.0. Armonk: IBM Corp; 2017.

Toyohara G, Fujihara M. Succession of secondary forests affected by pine wilt disease in western Japan followed on vegetation maps. Appl Veg Sci. 1998;1(2):259-66.

Vesk PA, Westoby M. Sprouting ability across diverse disturbances and vegetation types worldwide. J Ecol. 2004;92:310-20.

Yoon JW, Kim YS, Kim GS, Sung JW, Park KH, Lee CH, Shin HT, Yi MH. Community structure and environmental factors of the major type of Pinus densiflora populations in Korea. JFES. 2014;30(1):167-78.

\section{Publisher's Note}

Springer Nature remains neutral with regard to jurisdictional claims in published maps and institutional affiliations. 